\title{
Verbs in speech framing expressions: Comparing English and Spanish ${ }^{1}$
}

\author{
ROSARIO CABALLERO \\ Universidad de Castilla-La Mancha
}

CARITA PARADIS

Lund University

(Received 23 March 2016; revised 31 January 2017)

\begin{abstract}
In this study, we explore how direct speech is portrayed in English and Spanish SPEECH FRAMING EXPRESSIONS (SFEs). The study has two aims. Firstly, we survey the use of verbs in SFEs and offer a comprehensive inventory of those verbs in English and Spanish as representatives of Germanic and Romance languages respectively in order to determine what verb meanings are used to cue direct speech, what lexical resources express these meanings, and how rich and varied these vocabularies are in the two languages. Secondly, the comparisons across the languages provide the basis for a theoretical contribution to the debate about general typological differences in the semantics and lexicalization patterns of verbs in Germanic and Romance languages to the area of verbs for speech and to meaning modelling in general. Five main semantic categories of verbs were identified: SPEECH, ACTIVITY, PERCEPTION, COGNITION and EMOTION. We show that Spanish features a much more varied repertoire than English and makes more use of verbs related to the domains of thinking and reasoning, while the physical domain is the preferred one in the English data set. It emerges that even though the same types of lexical resources are available in both languages, the ways of describing direct speech vary greatly.
\end{abstract}

KEYWORDS: lexicalization, quotatives, semantic typology, verbs of communication, verbs of saying

\section{INTRODUCTION}

This is a large-scale study of verbs in SPEECH FRAMING EXPRESSIONS (SFEs) in a Germanic and a Romance language, drawing on data in English and Spanish works of fiction. SFEs are narrators' cues to how their readers should understand and assess what the characters say. We describe and compare what kinds of verb meanings are used to portray direct speech in fictional texts in the two languages, how these meanings are worded, how rich and varied the vocabularies are, and

[1] The present research is funded by the Spanish Ministerio de Economía and Competitividad MINECO (reference: FFI2013-45553-C3-2-P). We are grateful to three anonymous Journal of Linguistics referees and to the editorial team for their helpful comments. 
finally how the findings can be accounted for within the framework of Cognitive Semantics. There is a range of different types of SFEs and a large number of different verbs. Consider the SFEs in (1)-(4). ${ }^{2}$

(1) — ¿Qué ha pasado con mi madre? —les preguntó en un soplo de voz.

“"What has happened to my mother?" s/he asked them in a breathy voice.'

(2) 'How do you know that?' I whisper.

(3) 'I can't... I shouldn't,' Rose stumbled, finding her tongue at last.

(4) - Lo siento, Uru—reculó el Rition—, no era mi intención llamarte cobarde.

“"I'm sorry, Uru," backtracked the Rition, "it was not my intention to call you a coward.",

In (1) and (2) preguntó 'asked' and whisper are used to frame the preceding utterances, but they do so in different ways. In the Spanish example, the SFE expresses the fact that the speaker poses a question through the verb. The specific way in which the speaker does this is expressed subsequently in a prepositional phrase, en un soplo de voz - literally, 'in a breathy voice'. In the English example, the core of the SFE consists of the finite verb only, whisper, which profiles the manner of the action, i.e. how the question is uttered, leaving out what kind of speech act it is. Furthermore, the SFEs in (3) and (4), feature verbs with a wider scope of application and usage. In the English example in (3), stumbled refers to a faulty way of speaking in the physical domain, but its application in other contexts concerns bodily actions in which the legs rather than the voice are involved. However, stumbled is not only an expression referring to physical stuttering but also conveys a metaphorical meaning of hesitation in the mental world. Both readings are readily available. In contrast, like stumbled, reculó in the Spanish example in (4) may refer to a reversal in the physical world, but in this context the metaphorical backtracking in the sense of changing one's mind in the mental world is the more salient interpretation. What verbs and verb meanings are used to describe direct speech are intriguing questions in an emerging area of research where very little has been done. Through this investigation we hope to lay the empirical foundation for the semantics of verbs for speaking, and thereby contribute to the theoretical advancement of meaning modelling in the domain of speech, and also more generally (see Paradis 2015a).

Since we know very little about verbs for speaking in SFEs, the position we take as our point of departure is the extensive literature on verbs of motion.

[2] Since we are not concerned with the syntax of SFEs, the Spanish examples are not always wordfor-word translations, but are fully idiomatic. The main verb, however, has been translated as literally as possible to keep the flavour of the original. See Section 3.1 below for details of typographic conventions for the representation of direct speech in English and Spanish. 
The received view in typological work on motion verbs is that there is a tendency in English to plait together meaning properties of both motion and manner as in sashay, swagger, rush and dash, while Spanish has a preference for expressing motion and manner in separate lexical items, as in I must dash vs. Me voy corriendo 'me leaves running' and rush vs. ir de prisa 'move with a rush'. Both languages, however, feature manner-of-motion verbs, e.g. sashay/contornearse and swagger/fanfarronear. Research on the topic of lexicalization patterns in Germanic and Romance languages with focus on motion meanings was initiated by Talmy $(1985,1988,1991,2000)$, and has since then given rise to a lot of research also on other languages and other language families (Levinson \& Wilkins 2006, Filipović 2007, Zlatev, Blomberg \& David 2010, Slobin et al. 2014, Fagard et al. 2016). In addition to the alleged complexity of meanings lexicalized in English verbs, it has also been argued that rather than profiling MANNER of motion, as is the case in English verbs, Spanish verbs tend to profile PATH through the finite verb of motion. ${ }^{3}$ For instance, while Spanish has salir de puntillas 'leave on the tips of one's toes' with the action-path expressed by the finite verb and the manner of the action in a prepositional phrase, English, has tip-toe away, with manner expressed by the finite verb and the path through a modifying adverb (Slobin 2004, 2006).

Our investigation seeks to find out whether these tendencies, i.e. the contrast between English and Spanish in one-word vs. multi-word expressions for action and manner meanings, as is the case of verbs of motion, are maintained in the profiling of the verb meanings in SFEs and, therefore, the issues addressed in this paper start from the rich literature on typological differences of how motion is expressed in English and Spanish. Like motion verbs, verbs for speech are also about actions, more precisely about communicative actions. In order to determine how the two languages pattern in this respect, both in terms of what meaning structures are used and how varied and rich the vocabularies are, we focus on a specific functional category, namely SFEs. This enables us to make a systematic study of the constructions used for this purpose. We take all uses into consideration and thereby avoid cherry-picking constructions that we happen to encounter in texts.

For the purpose of our investigation, we compiled a seven-million-word corpus of 60 fictional texts, originally written in English and Spanish and representing three popular genres: fantasy, romance and crime. The reason for using these texts is that there is a lot of direct speech and a greater variety of verbs in SFEs than is the case in more descriptive types of fiction. The narrator does not leave it to the readers to form their own picture of the situation but takes care to provide them with clear pointers as to how they should interpret what the fictional characters try to convey, what they are like and what their relationships are in the light of how

[3] We use small capitals when referring to conceptual structure, single quotation marks for discursive meanings in language use and italics for language forms. 
they say things. We have devised a semantic analysis schema for the investigation of SFEs in order to see whether there are any formal, semantic and distributional differences between the two languages. Drawing on earlier work on verbs of motion, our hypotheses are:

(i) English verbs are more compact with respect to meaning packaging than Spanish, e.g. tip-toe/ir de puntillas) 'go on the tips of your toes'.

(ii) Activities and motion are the preferred meaning domains in English (e.g. put forward, burst out, sneak in), while for Spanish, mental meanings are preferred when direct speech is described (e.g. explicar 'explain', razonar 'reason', sugerir 'suggest'), in line with Caballero (2015).

The paper is organised as follows: After a short survey of approaches to speech verbs in Section 2, the corpus data, the selection principles and the analysis schema are presented in Section 3. The quantitative results of the various verb types and tokens are given in Section 4. The meaning types are then discussed in detail in Section 5. Section 6 offers a summary of the main results and a conclusion.

\section{BACKGROUND}

Different ways of representing speech in text have been examined by scholars in narratology and stylistics in literary research, and in different disciplines in linguistics ranging from discourse analysis, semantics, pragmatics to syntax. Although the goals and the approaches differ, the work carried out on the topic can be divided into two broad lines of research. The first one is concerned with the techniques in which speech is rendered in texts, i.e. direct, indirect and mixed speech (e.g. Coulmas 1986, Verschueren 1987, Maldonado 1991, Lucy 1993, Thompson 1996, Güldemann \& von Roncador 2002, Holt \& Clift 2007, Buchstaller \& van Alphen 2012). The focus of the other broad line of research is on the verbs used to introduce direct speech with special attention to the syntactic behaviour of the verbs (Dirven et al. 1982, Levin 1993, De Roeck 1994, Goldberg 1995, Klamer 2000, Suñer 2000) or their semantic properties (Wierzbicka 1987, Lehrer 1988, Rudzka-Ostyn 1988, Faber \& Mairal Usón 1999, Kissine 2010).

Like in most research fields, there is no consensus regarding the terminology used for verbs with the function of qualifying and explicating direct speech. In addition to verba dicendi, such verbs are variously referred to as linguistic action verbs (Verschueren 1987), verbs of saying/utterance/communication (Goossens 1990), or quotatives (Buchstaller \& van Alphen 2012). Since these cues to the reader include more than single verbs, we prefer to use the term Speech Framing Expressions (SFEs). The minimal SFE in our study is a finite verb, but more often there are concatenations of verbs and different kinds of modifiers. We adopt Clark \& Gerrig's (1990) notion of quotations as demonstrations, and Tannen's (1986, $1995,2007)$ view that what is referred to in the literature as reported speech, direct speech, direct discourse and direct quotation should not be understood as 
reporting but as constructed dialogue because "much of what takes the form of dialogue is by no means a "report" of what others have said but constructions by speakers to frame information in an effective and involving way' (Tannen 2007: 119). The notion of frame for descriptions of speech is also used by Vandelanotte (2012: 180), who states that

the reporting clause as a whole describes the speech act, the content of which is given in the reported clause. By the same token, the whole reporting clause tends to construe the deictic 'frame' ... containing the spatial, temporal and personal reference points with regard to which the quote is interpreted.

The motivation for our choice of terminology is that the most important function of SFEs is to frame and shape the readers' interpretations of what the speakers say. We see the narrators as go-betweens; they are intruders in the worlds of the role figures in the text and intruders-cum-facilitators in the worlds of the readers. Clearly, narrators do not just report; rather, they provide frames and qualifications to facilitate the alignment of the readers with the characters. As also pointed out by Rodríguez Ramalle (2008), SFEs are not obligatory elements in text and discourse. Direct speech is already marked typographically in the text and, therefore, it is perfectly possible to make do without them as shown, for instance, by Vargas Llosa in Los cachorros (The Cubs). Through his highly dialogic and polyphonic style, Vargas Llosa makes a point of NOT using SFEs and, in addition, mixes voices anacholuthically in streams of direct speech.

As noted in the introduction, there are very few studies that have been carried out comparing English and Spanish speech verbs in SFEs (Rojo \& Valenzuela 2001, Martínez Vázquez 2005, Caballero 2015). These studies are concerned with the ways in which speech events are lexicalised and how meaning structures are evoked through those expressions. They all confirm that SFEs make use not only of speech verbs such as, for example, say, ask, order and request but also of verbs that have other application areas in contexts other than SFEs, such as, for example, stumble, put in, frown, i.e., in this case, actions related to manner of motion, direction of motion and facial gesturing. In their work on speech events in text, those scholars are influenced by Talmy's $(1985,1988$, 1991) work on motion and his distinction between VERB-FRAMED LANGUAGES such as Spanish and SATELLITE-FRAMED LANGUAGES such as English. Talmy's typological distinctions are concerned with the lexicalisation patterns of motionrelated meanings in which satellite-framed languages are characterized by rich meaning structures conveying manner and/or cause of motion in the main verb, while the trajectories or paths of motion are expressed in the satellites which take the form of adverbials, prepositional phrases, affixes or particles, as in staggered out of the bar in (5).

\section{(5) The drunk man staggered out of the bar.}

On the other hand, as is shown in the Spanish example in (6), verb-framed languages lexicalize the trajectory or path of motion through the main verb, 
salió 'left' in (6), and express any other additional information, typically manner, separately, as with tambaleándose 'staggering' in (6).

(6) El borracho salió del bar tambaleándose.

'The drunk man went out of the bar staggering.'

Such different ways of construing the same meaning structures are likely to have an effect on how speakers of those languages experience and reason in the world, irrespective of how great or how subtle the differences are (Slobin 1996, 2004, 2006). What is not covered by Talmy's work are detailed and systematic analyses of the lexical resources and their meanings, their distribution and their contextual habitats in order to see if the claims about the typological differences really hold good. This is what we aim for in this study and this is also what Rojo \& Valenzuela (2001) did in their study of how verbs of saying are used in four novels originally written in English and in their Spanish translations. Their study shows that not only did Spanish translators use more verbs than the English authors (56 Spanish verb types versus the 46 English original ones), but those verbs were more varied than the ones found in the original works. For instance, say and tell abound in the English originals, while the Spanish translations use words for much more specific meanings such as aconsejar 'advise' or precisar 'specify' (see also Contreras 1988). From this, we may conclude that, in expressions describing speech, Spanish SPEECH verbs in SFEs seem to be like verbs in the motion domain: the verb meanings are rich and more specific.

Caballero (2015) paints a similar picture in her study of how English and Spanish render speech events. Her study is based on data from a corpus of twelve fictional narratives in English and their Spanish translations. Unlike Rojo \& Valenzuela (2001), Caballero includes all verbs that serve as SFEs, e.g. grin 'sonreír', scowl 'fruncir el ceño' or shrug 'encogerse de hombros', not only verbs of saying proper as Rojo \& Valenzuela (2001) did. Her study demonstrates that Spanish has the same lexical resources as English to describe speech events, but they are not used in the same way. In other words, the differences between English and Spanish do not involve what can be expressed. Like Rojo \& Valenzuela (2001), she found (i) a greater variety of verbs of saying, and (ii) more meanings related to cognition and reasoning in the Spanish texts. For instance, the English verb say is translated into Spanish as apuntar 'note', articular 'articulate, develop', brindar 'toast', comentar 'comment on, discuss', exponer 'show', explain', expresar 'express', indicar 'show', manifestar 'declare, express', observar 'point out, notice', ofrecer 'present, offer', opinar 'think', proferir 'utter' and razonar 'reason'. Moreover, while English texts make frequent use of sound and/or manner verbs, e.g. exhale, huff and tsk, and verbs providing gestural information, e.g. deadpan, frown and pout, Spanish texts make more frequent use of verbs referring to illocution and cognition to cue direct speech, e.g. advertir 'warn', protestar 'protest' or excusarse 'apologize' and comprender 'understand', conjeturar 'speculate' or deducir 'deduce'. What we 
learn from this is that Spanish speakers put more emphasis on mental matters concerned with the thoughts, reasoning and intentions related to the speech event than to physical dynamics. Analytical, explanatory and intellectual aspects of what is said are important and explicitly expressed in the Spanish translations, which is in stark contrast with the physical, dynamic, filmic style of the English original texts. In other words, English narrators favour perceptual and dynamic descriptions in SFEs to cue their readers' understanding of the participants' emotions, attitudes, intentions and states.

Like Caballero (2015), Martínez Vázquez (2005) also investigates the use of verb types in communicative acts in English and Spanish. She investigates the subcategorization patterns of verbs of saying within the framework of Construction Grammar à la Goldberg (1995). Besides conventional verbs of saying in the two languages, Martínez Vázquez identifies five groups of verbs of communication: (i) discharge verbs, e.g. cough/toser; (ii) cognitive verbs, e.g. reason/razonar; (iii) manner verbs expressing sounds emitted by humans such, as shriek/chillar, animals, such as bark/ladrar, and inanimate phenomena, such as thunder/tronar; (iv) instrumental verbs, such as telephoneltelefonear; and (v) gesture verbs, e.g. nod/cabecear and smile/sonreir. Drawing on corpus data from the British National Corpus (BNC) for English and El Corpus de Referencia del Español Actual (CREA) for Spanish, she also concludes that the use of single verbs of saying with a manner element, e.g. shriek, is more frequent in English than in Spanish, while there is a preference in Spanish for the use of constructions combining two verbs, as in decir estridentemente 'say stridently' - a finding that is in agreement with the differences between English (as a satellite-framed language) and Spanish (as a verb-framed language) found in motion research.

\section{DATA AND METHOdology}

In this section, we describe the corpus, the criteria for identifying SFEs and our categorization schema. We focus on the domain of speech in three genres of novels, i.e. not on isolated occurrences in sentences across different text types as in Martínez Vázquez (2005). Also, unlike Rojo \& Valenzuela (2001) and Caballero (2015) we make use of original texts rather than translations.

\subsection{The corpus and criteria for identification of SFES}

For the purpose of this study, we compiled a corpus of texts from three fictional genres in English and Spanish, namely fantasy, romance and crime (see Appendix A for titles and authors). Our corpus includes 60 novels in all, 30 original texts in English and 30 original texts in Spanish. The texts are evenly distributed across the three genres (10 texts for each genre and language) and across gender (i.e. five male and five female authors for each genre). The total number of words in the whole corpus is 7,111,754. The English data set consists of $3,393,947$ words and the Spanish data set is somewhat larger - 3,717,807 words. 
The identification of the SFE units was carried out in an indirect way through the identification of SFEs using the following strictly typographical criteria: (i) direct speech must be surrounded by quotation marks or by dashes, and (ii) the SFEs must be in the same sentence as the direct speech.

In relation to the marking of direct speech, it should be noted that English and Spanish follow different typographical conventions, see footnote 2 above. In English, inverted commas are normally used to mark what the speaker says, and the SFEs may appear before, inside or after the direct speech. The two components are separated by punctuation marks (commas, dashes, colons, full stops, question marks or exclamation marks). If the SFEs are placed immediately after the direct speech, no punctuation mark is used after the marks of the direct speech, which for English is the inverted comma, as in (7) below. In Spanish, on the other hand, direct speech is most often surrounded by dashes, and like in English, the SFEs may be located before, inside or after the marks, as in (8).

(7) 'I understand,' Evelyn concurred.

(8) — ¿Qué ha pasado con mi madre? — les preguntó en un soplo voz.

“"What has happened to my mother?" s/he asked them with a whisper.'

Next, we were strict about the sentence boundary. This means that all potential SFEs that for some reason appear outside the sentence were disregarded in this study. Such SFEs are of the type shown in (9), where the SFE is a sentence in its own right:

(9) Evelyn held her hand out. 'At least Avery won't be contesting the will if he's not in England.'

The reasons for the limitations are both qualitative and quantitative. We wanted a strictly formal, typological criterion for our categorization for this study because we expected the SFEs that occur outside the sentence boundary of the direct speech to differ from the SFEs inside the sentence boundary. The quantitative reason is that our data set is large as it is without SFEs outside the sentence boundaries, which means that we have more than enough data for our purposes.

\subsection{The semantic categorization}

As already stated in the introduction, the raison d'être for the use of SFEs is for the narrator of the novel to guide the reader's interpretation of the direct speech uttered by the fictional characters. Our semantic analysis is usage-based and situated in the broad framework of Cognitive Linguistics. The basic assumption is that word meanings are not fixed but crystallize when used in discourse (Cruse 2002, Paradis 2005, 2015a, Gärdenfors 2014). This investigation is concerned with the analysis of event types represented through the tensed verbs of the SFEs. Yet, for a proper fine-grained semantic analysis it is important to take the whole SFE into account. This becomes particularly obvious for the subcategories. 
The importance of considering the SFE as a whole is illustrated in examples (10) and (11):

(10) 'I am the emissary of Brother Peacock,' a low voice announced.

(11) 'I'll take them,' announced Ruso.

Whereas announce in (10) describes a disembodied voice and, therefore, places the focus on what is said as PERCEPTION, more precisely hearing, by the participants in the event, the SFE in (11) makes it clear that someone whose name is Russo is the one announcing something to the others and hence announce is classified as SPEECH. See also Section 5.3 for more examples of how the context surrounding the verb in SFEs affects the analysis.

Finally, the categorization schema was built up incrementally and the categorization was refined successively by two analysts who worked independently of one another in the first phase. Any tagging discrepancies were discussed and resolved in the second phase. As shown in Table 1 below, the top-level categories are SPEECH, ACTIVITY, PERCEPTION, COGNITION, EMOTION and AUX, besides SPEECH, the main types are ACTIVITY, PERCEPTION, COGNITION and EMOTION. SPEECH, ACTIVITY and PERCEPTION include subcategories (for the entire set of verbs, see Appendix B). Examples (12)-(16) illustrate each of the categories in full.

(12) 'Two minutes, it is. We'll be right out, I promise,' Zoe said. (SPEECH)

(13) 'The quintessential doormat you mean?' she inserted drily. (ACTIVITY)

(14) 'Tango, you got him?' I heard.

(PERCEPTION)

(15) 'I'm going home,' she decided.

(COGNITION)

(16) 'Absolutely free from error', he marvelled.

(EMOTION)

In addition to SFEs where the main descriptors are the tensed verb focussing on what is said and/or how the speaker says something or experiences something, there is also another, minor type of SFE, where the tensed verb is a copula or a verb expressing aspectual and motivational properties. In this study, we refer to these as AUXs. Consider examples (17)-(20).

(17) 'Would you look at this?' he kept saying.

(18) 'You can still stop this,' Merrick managed to whisper.

(19) 'What does that mean?' she demanded to know.

(20) 'Yes, but-' Arin looked weary and confused.

Some of the AUXs are followed by a non-finite verb, as in (17)-(19), while others are followed by adjectives, as in (20). This identification of the AUX class of verbs in SFEs is a result of our strict criterion to use the finite verb as the hub for the analysis. However, as we see in Section 5.6, this introduces a new and interesting dimension into the area of lexicalization patterns and meaning packaging within 
SPEECH - describes a character's speech through the way of saying

General: say, ask, answer, suggest, complain, plead

Manner

Human: mutter, shout

Animal: purr, bark

Inanimate: ring, chime

ACTIVITY - describes a character's speech through bodily motion

General: add, interrupt, cut, put in, snap, begin, finish, continue, stop, pause, shrug, read

Face (sonic or gestural): breathe, laugh, swallow, tsk, spit, pant, sneer, glare

Confrontation: shoot, fight, attack

Human force: press, manage, try, attempt

PERCEPTION - describes a character's speech through the senses

Hearing: hear, sound

Sight: see

Touch: feel

COGNITION - describes a character's speech through cognition reason, muse, wonder, recall, remember

EMOTION - describes a character's speech through emotions explode, burst out, marvel

AUX - copulas or aspectual markers

be, appear, begin, try, can

Table 1

Semantic categorization schema for verb meanings in SFEs.

and across languages. These verbs show similarities with tensed verbs expressing PATH through the tensed verb or through an adverb. This opens up new and interesting areas for more research. In the next section, we show the results of the main semantic categories, and discuss them in some more detail in Section 5.

\section{RESUlts}

This section reports on the main quantitative results of the study. Table 2 below shows the numbers of event types used to describe direct speech via a tensed verb in the corpus.

The figures in this table are raw figures from the data. In all, there are 26,204 SFEs in the English corpus and 29,545 in the Spanish one. This difference between the two languages is very small in the light of the sizes of the corpora. In total, there are 3,393,947 words in the English corpus and 3,717,807 in the Spanish one. In relation to the number of words, there are fewer SFEs in the 


\begin{tabular}{lrrrr}
\hline Category & English & $\%$ & Spanish & $\%$ \\
\hline SPEECH & 23,052 & 88 & 22,753 & 77 \\
ACTIVITY & 2,562 & 10 & 5,762 & 19 \\
PERCEPTION & 423 & 2 & 481 & 2 \\
COGNITION & 78 & 0 & 324 & 1 \\
EMOTION & 89 & 0 & 225 & 1 \\
Total & 26,204 & 100 & 29,545 & 100 \\
\hline
\end{tabular}

Table 2

The distribution of SFEs with tensed verbs across semantic categories in English and Spanish.

English data (77 per 10,000 running words) than in the Spanish data (79 per 10,000 running words). The reason for the actual number of SFEs may be due to the actual number of words per se, but it may also be a product of the dialogic density in the texts in the two languages. To investigate the differences across genres in the two languages is, however, beyond the scope of this study.

When comparing the distributional patterns in English and Spanish in Table 2, we note that verb meanings relating to SPEECH are by far the most common type in both languages. This is of course a natural consequence of the fact that SFEs are about how the fictional characters speak as a function of how they experience the situation described. Relatively speaking, however, SFEs relating to SPEECH are more common in the English data $(88 \%)$ than in the Spanish data $(77 \%)$. The reverse is true for ACTIVITY, COGNITION and EMOTION, which are more frequent in Spanish than in English. For PERCEPTION there is an even distribution. In Table 3, we show the tokens, types and the token-type ratios (TTR) across all the categories.

\begin{tabular}{|c|c|c|c|c|c|c|c|c|}
\hline \multirow[t]{2}{*}{ Category } & \multicolumn{4}{|c|}{ English } & \multicolumn{4}{|c|}{ Spanish } \\
\hline & Token & Type & TTR & $\%$ & Token & Type & TTR & $\%$ \\
\hline SPEECH & 23,052 & 238 & 97 & 0.3 & 22,753 & 317 & 72 & 0.4 \\
\hline ACTIVITY & 2,562 & 281 & 9 & 7 & 5,762 & 462 & 12 & \\
\hline PERCEPTION & 423 & 107 & 4 & 16 & 481 & 120 & 4 & 17 \\
\hline Cognition & 78 & 15 & 5 & 9 & 324 & 50 & 6 & 5 \\
\hline EMOTION & 89 & 24 & 4 & 10 & 225 & 59 & 4 & 12 \\
\hline
\end{tabular}

Table 3

SFE tokens, types and token-type ratios (TTR) and percentages of hapax legomenon verbs across categories and languages.

The table shows that the Spanish corpus has more tokens than the English one in all categories but SPEECH. The numbers within the category of speech are by 
and large similar across English and Spanish, but judging from the TTR there is more variation in the Spanish data (lower TTR). The percentages of the verbs that only occur once (hapax legomenon) are very low across the board in both languages. In addition to the above types of meanings in the SFEs, there is also the AUX category where there is a marked difference with respect to numbers in English and Spanish: 235 tokens were found in the English data and 1,164 in the Spanish data. In the next section, we discuss all the semantic categories one at a time, including the AUXs, followed by a summary of the observations.

\section{DisCUSSION}

With reference to our research questions presented in the introduction, here we discuss the results of our corpus analysis category by category. We conclude with a summary of our observations and the theoretical implications for semantic modelling. Our research questions concern (i) how direct speech is described through the verbs in the SFEs in dialogue in English and Spanish fictional texts in general, (ii) whether there are differences with respect to lexical variability, and (iii) whether there are typological differences mirroring the lexicalization differences proposed by Talmy (2000) and Slobin et al. (2014) for motion, and by Caballero (2015) for translation data of speech verbs.

In Section 4, we reported on the main quantitative patterns across both languages, and showed that there are more SFEs and verb types in the Spanish data, which suggests that there is more variation (see Appendix B). With respect to the numbers for each of the meaning categories, our results differ from Caballero's (2015) translation data in that English makes more use of verbs referring to SPEECH than Spanish does, and the opposite is true of verbs evoking meanings of ACTIVITY, PERCEPTION, COGNITION and EMOTION. In order to find out what the patterns are and what the differences really consist in, we take a closer look at the different uses and meaning categories. These are discussed in Sections 5.1-5.5 below. After that, in Section 5.6, we also take a look at the category AUX to examine how they pattern with respect to content.

\subsection{Speech SFEs}

Overall, there are more tokens of verbs for SPEECH in English $(19,865)$ than in Spanish $(18,167)$, but there are many more types of verbs in Spanish (317 versus 238 ), which indicates that there is a much higher degree of variability in terms of verb types in Spanish than in English. However, in this context it is important to note that, even though there are more verb types of SPEECH in the SFEs in Spanish, the entire SFE construction has to be taken into account since nuances may be expressed in other parts of the SFE, for instance, through modifying elements or through the subject or the object participants in both languages. What we show is that, with respect to the verbs used in SFEs, Spanish makes use of a larger number of verb types, and what we are concerned with here is the semantic 


\begin{tabular}{lrrrrr}
\hline \multirow{2}{*}{ SPEECH } & \multicolumn{2}{c}{ English } & & \multicolumn{2}{c}{ Spanish } \\
\cline { 2 - 3 } \cline { 5 - 6 } & Token & Type & & Token & Type \\
\hline General & 19,865 & 133 & & 18,167 & 229 \\
Manner-human & 2,786 & 72 & & 4,479 & 74 \\
Manner-animal & 343 & 21 & & 95 & 12 \\
Manner-inanimate & 58 & 12 & & 12 & 2 \\
\hline
\end{tabular}

Table 4

Token and type distribution of SPEECH SFEs in English and Spanish.

information expressed through the verb, i.e. the verbs rather than any other SFE elements are the objects of comparison in this study. Table 4 shows the exact numbers of the tokens in each corpus.

Within the category of speech, there are general speech verbs, there are speech verbs where manner is profiled or where interaction is profiled, and there are meanings that relate to humans, animals or things. First of all, it is important to state at the outset that the verbs say and decir are the most common ones in both languages, but they are not distributed in the same way in the two corpora. Say occurs 12,960 times and tell 671 times, while their Spanish equivalents decir and contar only occur 6,848 and 12 times, respectively. Moreover, Spanish also features a much greater variety of verbs of saying with some other aspect of meaning included in the mould, e.g. comentar 'comment on', anunciar 'announce', declarar 'declare', exponer 'expound', manifestar 'declare', notificar 'notify'. Naturally, similar possibilities are also available in English, but our corpus data show that they are not the preferred option. Compare the following sentences:

(21) 'I do not need you,' she enunciated clearly.

(22) - Creía que estabas conmigo para lo bueno y para lo malo—enunció con una mirada taxativa-

"I thought you were with me through good and bad," she enunciated with a sharp look.'

(23) 'She must be killed,' Lord Renly declared.

(24) - A mi esa teoría no se me habría ocurrido ni en mil años—declaró, poco convencida.

“"That theory wouldn't have occurred to me in one thousand years," she declared little convinced.'

All the verbs in (21)-(24) add nuances related to the speakers' attitudes or intentions to the meaning of saying itself. However, the English verbs enunciate and declare are not verbs that are commonly used in everyday conversation but tend to be used in more specific or formal contexts where the speaker not only states something, but does it in a very articulate, definite and resolute way. 
The Spanish verbs, on the other hand, are not associated with a high degree of formality and are widely used.

Another difference between English and Spanish is the number of verbs that evoke meaning aspects that clearly convey both speaker intentions and the dynamics of the interaction - in particular, the distribution and duration of the conversational turns. Indeed, if we remove the occurrences of the verb say $(12,979)$ and decir $(6,848)$ from the general subgroup of SPEECH in the two corpora, the remaining figures are 6,886 tokens for English and 11,319 tokens for Spanish, which indicates greater variability of expressions in Spanish. In addition to these very general verbs of saying, there is also a large number that contributes to the description of the reciprocal nature of the dialogue, e.g. preguntar 'ask', responder 'answer, 'respond', contestar 'answer', replicar 'reply', inquirir 'enquire', exigir 'ask', 'demand', rebatir 'counter', interrogar 'ask, interrogate', reclamar 'demand', hacer una pregunta 'ask a question', cuestionar 'question, ask', interpelar 'question, interrogate' consultar 'ask', indagar 'analyse' or requerir 'ask'. There are 5,747 occurrences of such verb meanings in the data for Spanish. The corresponding figure for English is 3,642 with verbs such as ask, reply, answer, demand, respond, retort, query, counter and inquire. All in all, there are six types fewer than in Spanish.

A final difference concerns manner of speaking verbs, particularly those conveying meanings that are associated with the sounds of animals and inanimate entities. While the texts in both languages are similar with respect to the number of manner-human verb types, 72 in English and 74 in Spanish, the English texts are richer in manner-animal verb types, 21 in English and 12 in Spanish. The animals involved are similar in the two languages, even if English verbs are more varied. Most of them have to do with hoofed animals such as bulls or deer (English bellow/Spanish bramar), predators such as lions or wolves (roar/rugir, howl/alular), pets such as dogs and cats (bark/ladrar, purr/ronronear) and crows (graznar and urajear in Spanish and the English equivalents caw, squawk, croak, crow). Finally, the numbers of verb types referring to manner-inanimate types are 12 in English and two in Spanish. English texts make use of all kinds of sounds (grate, thunder, trumpet) - from loud to high-pitched noises - and outnumber Spanish texts, which use only tronar 'boom, thunder' and restallar 'crack' for loud and sharp noises, respectively. In other words, while Spanish is richer and more nuanced in general speech verbs, English has more verbs specifying different manner types relating to animals and inanimate entities.

\subsection{Activity SFEs}

Like verbs expressing meanings in the SPEECH domain, verbs related to ACTIVITY, e.g. are more frequent in Spanish than in English texts. Table 5 below shows the breakdown into the subcategories and tokens.

As shown in this table, the SFEs referring to ACTIVITY are more than twice as numerous in the Spanish texts $(5,762)$ as in the English texts $(2,562)$. The pattern 


\begin{tabular}{lrrrrr}
\hline \multirow{2}{*}{ ACTIVITY } & \multicolumn{2}{c}{ English } & & \multicolumn{2}{c}{ Spanish } \\
\cline { 2 - 3 } \cline { 5 - 6 } & Tokens & Types & & Tokens & Types \\
\hline General & 1,937 & 184 & & 4,326 & 343 \\
Face & 523 & 85 & & 1,329 & 140 \\
Confrontation & 43 & 8 & & 98 & 27 \\
Human force & 59 & 4 & & 9 & 6 \\
\hline
\end{tabular}

Table 5

Token and type distribution of ACTIVITY SFEs in English and Spanish.

is the same within the subcategories except for the verbs referring to human force where English has more tokens. Also with respect to types, Spanish outnumbers English. In all, the English texts feature 281 types and the corresponding number for the Spanish texts is 462 types.

In Spanish, 3,017 instances of ACTIVITY verbs function as dialogue managers. Among them 2,036 belong in the subtype referred to as general, 59 in the FACE subtype and 42 in CONFRONTATION. There are fewer dialogue management uses in the English corpus. In the GENERAL subgroup there are 1,249 instances that are used to describe the dialogic exchange, 40 profile ACTIVITY FACE, three profile CONFRONTATION and one HUMAN FORCE. The number of types that fulfil these roles is very similar in the two languages, with the exception of CONFRONTATION verbs such as atacar 'attack', contraatacar 'counterattack', asaltar 'assault', abrir fuego 'open fire' or rematar 'finish off', which have more types in Spanish than in English, i.e. conversations are more often portrayed as battle fields, as in $(25)$.

(25) — ¡Pero si ese descolorido no es tu tipo! — atacó Patricia cogiendo un tercer donut.

—Ni el tuyo el calvo—contraatacó Marta.

"“But if that colourless/bland [man] is not your type!" attacked Patricia taking a third doughnut.

"Nor is the bald one yours," counterattacked Marta.'

The most frequent ACTIVITY verbs in both languages are the ones that bring to the fore the aspectual quality of turns of speech such as add/añadir, continue/continuar, interrupt/interrumpir, or concludelconcluir, go on/seguir, turn/volverse or break in/prorrumpir. Contrary to our expectations, the Spanish corpus contains more motion meanings than the English counterpart, both in terms of types and tokens. While there are 130 tokens and 20 types of motion instances in English, e.g. turn, stop, break in, trail off, the corresponding numbers for Spanish are 407 tokens and 44 types. The most common ones among these are prorrumpir 'burst into', avanzar 'advance', anticiparse and adelantarse 'overtake', frenarse 'brake, stop', lanzarse 'launch'), volverse 'turn around', atajar 
'make a shortcut', dirigirse 'go toward', seguir 'go on', embalarse 'accelerate', 'speed up' and arrancarse 'rush off'. Full examples of such uses from the Spanish and English parts of the corpus are given in (26) and (27).

(26) - Hay mucho trabajo, somos pocos, los cadáveres se acumulan... -Dolores se embala en una retahíla de excusas hasta que, de pronto, se detiene- - Qué quieres que te diga, es pronto.

“"There's a lot of work, we are few, the corpses are piling up...” Dolores speeds up with a list of excuses until, suddenly, she stops. "What do you want me to say, it is early."'

(27) 'It don't matter what her name is,' Luke broke in. 'She ain't no concern of yours.'

\subsection{Perception SFEs}

The category of PERCEPTION has four subcategories: general, hearing, sight and touch. With respect to the category as a whole, there are no big differences between the uses in the two languages. The Spanish corpus comprises 120 types and 481 tokens, and the English corpus contains 107 types and 423 tokens. Also with regard to the distribution across the subcategories, the languages pattern in the same way, as shown in Table 6.

\begin{tabular}{lcrrrr}
\hline \multirow{2}{*}{ PERCEPTION } & \multicolumn{2}{c}{ English } & & \multicolumn{2}{c}{ Spanish } \\
\cline { 2 - 3 } \cline { 5 - 6 } & Tokens & Types & & Tokens & Types \\
\hline General & 19 & 1 & & 15 & 6 \\
Hearing & 382 & 97 & & 446 & 112 \\
Sight & 4 & 2 & & 7 & 3 \\
Touch & 0 & 0 & & 13 & 7 \\
\hline
\end{tabular}

Table 6

Token and type distribution of the PERCEPTION SFEs in English and Spanish.

The table presents the distribution across the four subcategories. GENERAL refers to meanings where no specific sensory modality is referred to in the SFEs, and here English has 19 tokens of one type, while Spanish has 15 tokens and six types. The Spanish verbs that are used to express sensory experience in general in our corpus are notar, advertir, apreciar, parecer, percibir, sentir, all of which may be rendered in English as feel, sense and notice - even if notice is often used as a sight verb in English rather than a general-perception one. Consider (28) and (29): 
(28) En el coche no podía dejar de pensar en lo que había sucedido. Mi compañero enseguida lo notó:

- ¿Hay algo que le preocupa?

'In the car, I couldn't stop thinking about what had happened. My colleague immediately noticed, "Is anything worrying you?",

(29) Aterrizaron en un hospital .... Por suerte, una de las enfermeras no tardó en reconocer a la anciana y, discretamente, se dirigió hacia ellas con la primera camilla que encontró en su camino:

-Acompáñenme, por favor.

—Tranquila, esperaremos-Minerva advirtió el privilegio injusto.

'They landed in a hospital ... Luckily, one of the nurses didn't take any time to recognize the old woman and, discretely, approached them with the first stretcher that she found in her way: "Come with me please."

“Don't worry, we will wait," Minerva noticed the unjust privilege.'

In these examples, the verbs notó and advirtió make no reference to the specific sense involved in the speakers' experience of an event. The description of the direct speech is presented as a holistic experience. Moreover, as discussed in the next section, both these verbs may be translated as realize, leaning towards cognition, which is another type of verb meaning more often found in Spanish SFEs than in English.

Finally, as is also clear from the numbers of PERCEPTION SFEs in Table 6, most SFEs include verbs which refer to meanings related to hearing. This auditory experience may be portrayed in two ways: on the one hand, it may describe the sound of what was uttered, focusing on its source; on the other, it may place the focus on the hearer and can thus be described as internalized and target-oriented. Both perspectives are exemplified in examples (30)-(33).

(30) 'I am the emissary of Brother Peacock,' a low voice announced.

(31) ¿Es usted Maria Puente? —me pregunta una voz masculina.

““Are you María Puente?” a masculine voice asks me.'

(32) 'Gods!' he heard behind him.

(33) — ¿Y cómo fue? — reconozco la voz de Eugenio.

“"And how was it?” I recognize Eugenio's voice.'

The source-oriented perspective is exemplified in (30) and (31), where voice/voz are important pieces of information in the SFEs. The pattern of use in both languages involves verbs which are either speech verbs, e.g. English answer, shout and, above all, say, and in Spanish decir 'say', gritar 'scream' or anunciar 
'announce', or action verbs, e.g. come/llegar, continue/continuar, return/regresar. The internalized, target-oriented perspective is exemplified in (32) and (33), expressed by a perception verb with reference to one of the participants in the interaction.

It is worth noting that, while the meaning types may be the same in the two languages, the actual verb tokens used are not the same. Again, this has interesting implications for the alleged typological differences between English and Spanish in their use of PERCEPTION SFEs. The English corpus only contains five perception-proper verbs, among which we find three hearing verbs (hear, sound and overhear) responsible for 89 occurrences, two sight verbs (notice and glimpse) occurring four times, and the verb feel referring to touch, which occurs only once. The remaining occurrences describe source-oriented scenarios where voice is predicated by a speech verb or an activity verb, among which say is the most frequent (73 tokens), followed by come (36), call (32), ask (14), whisper (9), and shout (8). All other verbs occur less than five times and most often express manner meanings. In contrast, the Spanish corpus has 16 perception verb types (oir 'hear', escuchar 'listen', sonar 'sound', sentir 'feel', notar 'feel, notice, realise', ver 'see', apreciar 'see, discern', detectar 'detect', reconocer 'recognise', doler 'hurt', escocer 'sting', quemar 'burn', advertir 'see, notice, realise', parecer 'seem', percibir 'perceive'). These amount to 190 tokens of which 141 are oir 'hear' and escuchar 'listen'. All these SFEs offer a target-oriented scenario where the focus is on perception and reception, i.e. on the addressee in the interaction, rather than the speaker or the quality of the utterance. The remaining 291 cases are SFEs with speech verbs (with decir 'say' occurring 69 times, and the rest evenly distributed between general and manner verbs), activity verbs, e.g. temblar 'tremble', llegar 'arrive' and regresar 'return', and emotion verbs, e.g. sobresaltarse 'get startled', atormentar 'torment' and impacientarse 'get impatient, lose patience'.

\subsection{Cognition SFEs}

One of the domains where there are striking differences between English and Spanish, both qualitatively and in terms of numbers, is COGNITION, as shown in Table 7.

\begin{tabular}{cccccc}
\hline \multirow{2}{*}{ COGNITION } & \multicolumn{2}{c}{ English } & & \multicolumn{2}{c}{ Spanish } \\
\cline { 2 - 3 } \cline { 5 - 6 } & Tokens & Types & & Tokens & Types \\
\hline & 78 & 15 & & 324 & 50 \\
\hline
\end{tabular}

Table 7

Token and type distribution of the COGNITION SFEs in English and Spanish.

The 15 types and 78 tokens in English contrast with the 50 types and 324 tokens in Spanish. In Spanish, the most common verbs aredecidir 'decide' (47), 
recordar 'remember' (39), dudar 'doubt' (34), suponer 'suppose, imagine' (24), comprender 'understand' (16), adivinar 'guess' (15), deducir 'deduce' (13), meditar 'meditate' (12), and reflexionar 'reflect, think' (12). The rest are all below 10. In English, muse occurs 40 times and wonder 12 times. The rest of the verbs occur only once or twice, e.g. guess and decide. Furthermore, the English COGNITION SFEs focus on the speakers, whose cognitive activity appears to be detached from the verbal interaction itself, while most Spanish SFEs are directly related to what is being said in the interaction, e.g., suponer 'assume', comprender 'understand', adivinar 'guess' and deducir 'deduce'. They invoke the inferential processes necessarily involved in understanding what is discussed among the participants in the conversation. Compare the following passages:

(34) 'No,' Jim said. 'I am profoundly interested in remaining alive.'

'Are you? I wonder,' LeBouef mused, regarding him ...'You have nothing. No family. No home. You belong nowhere. ...'

'I wouldn't worry. Lightning doesn't strike twice.'

'Doesn't anyone ever call you that, among all your many nicknames?' she wondered as they walked back through to the hall.

(36) - Imagino que por eso hablaba en susurros - añadió Valbuena—, por si se grababa la conversación y la voz podía servir luego para localizarle.

—Pero la conversación no se grabó—-deduje.

“"I guess that's why he spoke in whispers," added Valbuena, "just in case the conversation was recorded and the voice could later on be used to locate him."

"But the conversation didn't get recorded," I deduced.'

(37) - Somos los nuevos vecinos-dijo Emu intentando estrechar la mano de aquel hombre.

— ¿Vecinos? — dudó el hombre aceptando su saludo-. ¿Y qué se les ha perdido a una joven pareja como ustedes en Cumbria? ...

— Simplemente buscamos un lugar donde vivir-comentó Emu con cortesía.

—Oh, ¿aburridos del gentío? — supuso el anciano algo más tranquilo —.

"'We're the new neighbours," said Emu trying to shake that man's hand.

"Neighbours?" doubted the man accepting his greeting. "And what brings a young couple like you to Cumbria?" ...

"We're just looking for a place to live," commented Emu politely.

"Oh, bored with the crowd?" assumed the old man a bit more at ease.' 
The English verbs muse and wonder in (34) and (35) combine the actions of thinking and speaking, presenting the former as a dynamic, audible process where the speakers' attitude to what is being said is highlighted. While this is also the case in the Spanish examples (36) and (37), the focus here is not so much on what is being said or the speaker's attitude, but on the processes involved in understanding what is being conveyed. Thus, although the Spanish dudó 'doubted' and supuso 'assumed' cue the questions in the direct speech, this is not their main function; dudó conveys the speaker's doubts rather than just specifying the question and supuso refers to an assumption made by the fictional character. The findings reported about COGNITION are in agreement with what Caballero (2015) found in her translation data, namely that Spanish narrators' tend to elaborate on the cognitive aspects underlying speech events, irrespective of whether these concern the reasons for the participants' utterances or the reasoning processes themselves.

\subsection{Emotion SFEs}

Similar to the use of verbs in the SFEs in COGNITION, the differences between English and Spanish in the EMOTION category also concern the number of tokens found in each corpus and the semantics of the verbs. Consider Table 8.

\begin{tabular}{llllll}
\hline \multirow{2}{*}{ EMOTION } & \multicolumn{2}{c}{ English } & & \multicolumn{2}{c}{ Spanish } \\
\cline { 2 - 3 } \cline { 5 - 6 } & Tokens & Types & & Tokens & Types \\
\hline & 89 & 24 & & 225 & 59 \\
\hline
\end{tabular}

Table 8

Token and type distribution of the EMOTION SFEs in English and Spanish.

Most of the English SFEs are associated with physical experience, and the verbs involved provide either a metaphorical, yet highly conventionalized, representation of emotions as natural forces (e.g. explode, storm), fire (e.g. seethe, fume, flare, blaze) or the physical reaction to emotional states (e.g. blush, brighten, pale). Such uses are also found in the Spanish corpus (e.g. estallar 'explode, burst', explotar 'explode', ruborizarse 'blush', tensarse 'become tense'); however, most EMOTION verbs in Spanish have the same intellectual flavour as the types in COGNITION. Before taking this point further, consider examples (38) and (39).

(38) 'You are not going to blame me for this too, Sandro...' she fumed impotently,...

'The only reason you're here now is because of my father ...' 'Don't you ever,' he suddenly seethed, grabbing and gripping her hand so tightly he cut off the circulation 'lump yourself into the same category as your father again, Theresa ...' 
(39) — ¿Una semana? — se sorprende_- Pues podría hablar con mi madre para que se quede con María. María es la pequeña, se llama como mi hermaname informa-. Y llamar a Luisma, Luisma es mi ex-me sigue poniendo al día-, para que se quede con Mateo y con Pablo, que son los mayores, pero...

—Pero nada, está decidido—se entusiasma Eugenio—- Te vienes conmigo a Nueva York. Yo te invito.

“"One week?" she is surprised. "I could talk to my mother so that she takes María. María is the youngest, she is called like my sister," she tells me. "And phone Luisma, Luisma is my ex," she goes on updating me "so that he takes Mateo and Pablo, who are the oldest, but..."

"But nothing, it is decided," gets excited Eugenio. "You're coming to New York with me. I invite you.",

The Spanish verbs are very explicit about the kind of emotions involved, presenting them as internal processes by means of reflexive verbs such as sorprenderse 'be/become surprised' and entusiasmarse 'be/become enthusiastic/excited', while the English verb meanings are more physical. Although the conventional interpretation of anger as ANGER IS SEETHING, it can also express a state of agitation or excitement. Both fume and seethe in English evoke a vivid image of someone that is red-faced and steaming with anger rather than an inner state of commotion.

\subsection{Auxiliary SFEs}

In addition to the semantic categories already discussed there is also another type of SFEs, consisting of meanings that describe the direct speech with regard to aspectuality or modality. The AUXs in our two corpora profile the start, the continuation or the end of an event, a state or a change of state, aspects of speaker force, wish and ability. These five categories are shown in Table 9.

Formally speaking, AUX verbs fall into two distinct patterns. On the one hand, we find the copular verbs be and estar followed by a non-finite verb denoting a state, as shown in examples (40) and (41):

(40) 'You can't simply stay at home,' she was appalled by that notion. 'You're the boss.'

(41) - ¿Y solo con eso partirías a alguien por la mitad? — Lizbeth estaba espantada-

“"And just with that, you would split someone in two?" Lizbeth was terrified.' 


\begin{tabular}{|c|c|c|}
\hline AUX & English & Spanish \\
\hline Start/continuation/finish & $\begin{array}{l}\text { continue, begin, } \\
\text { start, keep }\end{array}$ & $\begin{array}{l}\text { comenzar, volver, seguir, } \\
\text { continuar, dejar, empezar }\end{array}$ \\
\hline State and change of state & $\begin{array}{l}\text { be, appear, } \\
\text { look, seem }\end{array}$ & $\begin{array}{l}\text { parecer, tornarse, hacerse, } \\
\text { volverse, sonar, ser, estar }\end{array}$ \\
\hline Human force & $\begin{array}{l}\text { attempt, try, have to, } \\
\text { force oneself, hasten }\end{array}$ & $\begin{array}{l}\text { acertar, alcanzar, conseguir, } \\
\text { intentar, lograr, tratar, limitar }\end{array}$ \\
\hline Wish & $\begin{array}{l}\text { want to know, } \\
\text { demand to know }\end{array}$ & $\begin{array}{l}\text { desear, querer, querer saber, } \\
\text { exigir, saber }\end{array}$ \\
\hline Ability & can & poder \\
\hline
\end{tabular}

Table 9

AUX contributions and examples in English and Spanish.

The second pattern consists of aspectual or modality AUXs followed by a nonfinite verb describing a process or a state, as illustrated in examples (42)-(49):

(42) 'Would you look at this?' he kept saying.

(43) — ¿No han dicho sus nombres? — siguió preguntando-.

“"They haven't said their names?" s/he went on asking.'

(44) 'I feel guilty,' George managed to say.

(45) - Pero...pero....Eleonora y Dominic son hermanos-consiguió decir Lena.

"But... but. .. Eleonora and Dominic are siblings," managed to say Lena.

(46) 'But when are you coming home?' her mother wanted to know.

(47) — ¿Por qué te fuiste, entonces? — quiso saber.

"Why did you left then?" s/he wanted to know.

(48) 'Stop it,' Theresa could stand it no more.

(49) —Creo que sería una magnífica idea—no pudo reprimir decirlo.

"'I think it would be a great idea," he couldn't refrain from saying it.'

Similar to the categories discussed in the earlier sections, the Spanish corpus produced a larger number of both types and tokens in the AUXs category than the English corpus: 235 tokens in the English data and 1,164 tokens were found in the Spanish data. In addition to the differences with respect to the total number of occurrences of AUXs in the two languages, the distribution of the functions of types is not the same either. While most English uses involve copular constructions with a stative meaning and a verb referring to the speakers' attitude 
(98 tokens out of 235), most of the Spanish profile activity in the aspectualizer category, e.g. comenzar 'begin' and seguir 'continue' (554 tokens out of 1,164), and usually have a dialogue management role. Next are the auxiliaries of the human force type, e.g. intentar and tratar 'try' and lograr 'manage', which amount to 182 tokens copular patterns with ser and estar 'be' and the like (166 tokens and constructions with cognition and emotion verbs such as decidir 'decide', ocurrírse 'occur, come to mind', and, above all, querer 'want, like' followed by saber 'want to know', the latter type with 83 tokens out of a total of 162 in this group.

While always also taking the whole SFE into account for the identification of the interpretation of the verb meaning, we use the tensed verbs as the central element. Given this procedure, the AUX constructions have emerged as a construction that did not fit neatly into the other categories. This type of verb constructions needs more attention and analysis and it puts the spotlight on the fact that meanings are distributed in a range of different ways. In the next phase of our research, we will look into this more closely.

\subsection{Summary and analysis of the results}

This section sums up the results and discusses them in relation to the claims made about the literature on verbs of motion, speech verbs in the translation literature and in relation to the assumptions within the framework of Cognitive Semantics. The basic theoretical premise is that the use of words provides cues that evoke meaning structures in conceptual space (Cruse 2002, Paradis 2005, 2015a, Gärdenfors 2014). The way we perceive the world is reflected in the way we talk about it. Cultural patterns, both similarities and differences, show up in how we express ourselves through language. The content of cultural patterns pertains to both conceptual-affective patterns and to behaviour patterns in the cultural complex formed by the cognitive organization of its members (Talmy 2000: 373-375). In this section, we start with the similarities and differences and then proceed to discuss the theoretical implications of a study of this kind.

On the basis of the work done on translation data from English into Spanish (Caballero 2015), we expected Spanish narrators to describe direct speech with a focus on the speakers' intentions and mental states by mainly using SPEECH and COGNITION verbs, while English narrators would focus on meaning aspects related to ACTIVITY and MANNER descriptions. Our data partly contradict and partly corroborate these assumptions. We have shown that SPEECH verbs are the most common type of verbs in SFEs in both the English and Spanish texts, but relatively SPEECH verbs are more common in English than in Spanish. However, the opposite is true of ACTIVITY, PERCEPTION, COGNITION, EMOTION and AUX. Also, the Spanish vocabulary in the SFEs is overall much more varied, which means that there are fewer tokens per type of verb meaning. This is particularly striking for verbs of SPEECH. The opposite is true of Spanish verbs of ACTIVITY in comparison to English, where there are many more types than in the 
very common category of speech (in Spanish there are 462 types of ACTIVITY verbs compared to 317 for SPEECH, and in English the numbers are 281 and 238, respectively, as shown in Table 3). The token/type ratios of PERCEPTION, COGNITION and EMOTION are low in both languages, which is a sign that the narrators take care to describe the fictive speakers' contributions in a varied way and do not use clichés and prefabricated phrases.

Another unexpected finding is that our data contradict observations made in the motion literature, where the claim is that Spanish verbs are simpler than English verbs in their verb semantics with respect to MANNER as part of the verb itself (Slobin 1996, 2004, 2006). This is not true of our data, where Spanish exhibits fine-tuned specifications of different kinds through the verbs used in all the categories. Spanish shows more variation and nuances than English with respect to how the readers are instructed to understand and reason around what is communicated. For instance, with respect to the common core verbs of SPEECH, we show that English makes more use of the verbs at the top of the troponymy, i.e. general purpose verbs such as say and tell than Spanish does. This is in stark contrast to the findings in Slobin et al. (2014), who report the opposite pattern for verbs for motion in Spanish and English. In their data, based on a naming task, common core verbs such as go/ir, walk/andar and run/correr are far more common in Spanish than in English. There may be different explanations for this. One reason may be that there is in fact a difference between expressions for concrete motion and speech across the two languages. Another reason may be that the observational techniques produce very different results. A large-scale corpus study comprises a large body of natural data that are produced without any restrictions and instructions from an experiment leader, whereas the responses to experimental trials, which in this case are triggered by a set of visual prompts, tap into a very different type of knowledge. The use of verbs in a naming task is severely delimited by the scope of the task and the potential candidate verbs, and it is also limited with respect to the actual number of trials.

Furthermore, when we take a closer look at the usage at a subtler level within the different top-level categories, we observe that there is an intellectualizing inclination in Spanish, which is evidenced through the fact that most verbs in the Spanish SFEs are primarily used to explicate the act of speaking itself and/or the mental aspects involved in the interactions, regardless of which top-level semantic type of verb is used. For instance, in Spanish, most ACTIVITY verbs are interactional in that they spell out how the turn-taking in the dialogues is regulated by the fictional characters in order for them to pursue their intentions. In a similar way, the focus of verbs of PERCEPTION, COGNITION and EMOTION is on the fictional characters' noticing processes through target-oriented verbs such as reconocer 'recognise' or advertir 'notice', and the various mental operations involved in the process of understanding what is being said, what must be inferred and the ensuing reaction through verbs such as animarse 'cheer up' or escandalizarse 'be shocked'. The most straightforward type of verbs with this function is SPEECH verbs, which are explicit as to speakers' intentions, 
either through the verb itself (e.g. clarify, greet) or in the SFE construction as a whole (e.g. say with a frown). The SFEs found in the Spanish corpus typically focus on the most critical elements of the speech events, namely the act of saying something, including both turn-taking management and the participants' intentions and reactions to what is communicated in the direct speech. What we see for the Spanish SPEECH verbs in the SFEs may be said to mirror the focus on PATH in motion verbs in that in both cases the trajectory is in focus, i.e. the PATH of the communicative acts and PATH in motion acts as described by Talmy (2000). The trajectory of these verb meanings includes aspects such as who starts speaking, whether s/he pauses or not, who continues speaking and who may interrupt. A number of these aspects are also found among the AUXs.

In contrast to the mental focus in Spanish, there is a tendency in English to focus on the physical and dynamic aspects of speech events. The English texts make more frequent use of manner verbs concerned with the physical-auditory component of speech - manner-human, manner-animal and manner-inanimate verb meanings (e.g. stutter, cackle and thunder, respectively). There is a large number of source-oriented SFEs referring to the voice and to cognition and emotion verbs profiling the speakers' saying out loud what they have in mind or showing a physical reaction to an emotion, e.g. muse or blush, both of which turn mental acts into more physical ones. English SFEs are typically not concerned with explications and interpretations of the messages conveyed; rather, their main focus is to depict the flow of the interaction. Those descriptions differ from the Spanish ones in that the meanings are basically conveyed by means of manner expressions either as part of the main verb or as a modifying element.

This study has examined the lexical resources from a conceptual perspective and the results have important theoretical implications for the modelling of meaning-making in human communication and for descriptions and explanations of WHAT meanings are evoked by what lexical resources in two typologically different languages, and inversely HOW different conceptual domains are expressed through language in those languages. At the general level, the linguistic representation of conceptual structure is of central concern and the theoretical contribution of this article is to the very fundamental question of how words are used to express meanings in different domains and in different languages (KoptjevskajaTamm 2015). For that purpose, large-scale investigations of language use in discourse are crucial in order for researchers to make theoretical claims about word-meaning pairings in different domains. Lexical modelling requires a robust empirical foundation to account for how meanings are realized and how we actually use language (Paradis 2016). This rich empirical material, including the extensive lists of verbs for SPEECH in SFEs, offered in the Appendix B, shows what the lexical resources in the two languages are, highlighting the great variation both in terms of founding domains and lexical variation. This kind of manually annotated semantic typology offers a window into how meanings, in actual fact, are expressed in human communication. What we observe is that many expressions are not the kind of expressions that speakers would come up with if 
asked, which gives support to the idea that words do not 'have' set meanings, rather words are associated with a use potential in conceptual space and specific meanings are evoked on the occasion of use in discourse (e.g. Paradis 2004, 2015b, Jones et al. 2012).

We have demonstrated how conceptual domains and language elements relate to one another in SFEs. The two languages share aspects of meanings for this specific use, but at the same time they differ in rather interesting ways. Spanish SFEs are INTROVERT in the sense that they provide explicit information about sensory responses and ways of thinking and understanding in relation to what the speakers communicate, while English description of speech events are EXTROVERT in the sense that thoughts and feelings have to be extracted and inferred from the behaviour of the speakers. Such findings point to the existence of cultural patterns. Cultures may be Cultures with an uppercase letter, i.e. typological differences across languages, and cultures with a lowercase letter (Majid \& Levinson 2011, Caballero \& Paradis 2015). The latter relates to cultures within Cultures, which in our case pertains to SPEECH, more precisely to how narrators tend to guide their readers' understanding of what the speakers communicate.

\section{Conclusion}

This study set out to investigate WHAT verb meanings are used to cue direct speech in SFEs in English and Spanish dialogue in fiction texts, WHAT lexical resources there are to express these meanings in the two languages, HOW the meanings are lexicalized AND TO WHAT EXTENT the vocabularies vary. Drawing on studies of typological differences between lexicalization patterns in English and Spanish in the motion literature (Talmy 2000, Slobin et al. 2014) and corpus study of SFEs in texts translated from English to Spanish (Caballero 2015), we hypothesized that English verbs are more compact with respect to meaning packaging than Spanish verbs, and that reference to activities is more common in English (e.g. put forward, burst out, sneak in), while mental meanings are preferred in Spanish when direct speech is described (e.g. explicar 'explain', razonar 'reason', sugerir 'suggest'). Five top-level semantic categories were identified: SPEECH, ACTIVITY, PERCEPTION, COGNITION and EMOTION. Naturally, SPEECH is by far the largest category in both languages, with say/decir as the most frequent verbs, but in contrast to the findings about motion verbs (Slobin et al. 2014), English makes more use of general common core items than Spanish. The English data include more uses of verbs for SPEECH than the Spanish data, while the Spanish texts feature more verbs for ACTIVITY, PERCEPTION, COGNITION and EMOTION. We also identified a minor category that we refer to as AUX, which includes expressions with more than one verb or a verb and an adjective phrase. These aspectualizing and modalizing constructions are more common in Spanish than in English.

Through this large usage-based corpus study of the semantics of verbs in SFEs in English and Spanish we hope to have enriched and helped balance the picture 
of the typological differences between the two languages in the use of verbs to describe speech. By and large, our findings provide support to Caballero's (2015) characterization of the differences between English and Spanish in that there is a focus on mental events in Spanish rather than on physical events. The Spanish narrators are more analytical. They promote explication and reasoning, focusing what is on the speakers' minds. In contrast, the English narrators set the scene, showing what is going on in a filmic way. What we found for verbs of SPEECH is that there is also a preference for verb meanings that profile the PATH trajectory of communication in Spanish in a way similar to the trajectory of PATH in expressions of motion events in Spanish. However, in Spanish, there are also more verbs specifying MANNER of SPEECH than in English, which is surprising in the light of the reverse findings reported in the literature on verbs of motion. An important finding is that it that Spanish is richer than English in its resources of verb expressions in SFEs, both qualitatively and quantitatively.

From a theoretical point of view, it is obvious through this investigation that words are fickle creatures with a great potential for dynamic use in different domains. The long list of verbs used in the SFEs, presented in Appendix B, is evidence of the richness and the flexibility of the meanings of words in discourse which act as prompts for the activation of different attentional foci.

\section{APPENDIX A}

\section{The English and Spanish corpora}

English: 3,393,947 words

\section{Fantasy}

Tempest Rising (Nicole Peeler), The Falconer (Elizabeth May), The Winner's Curse (Marie Rutkoski), Throne of Glass (Sarah Maas), Geist (Philippa Ballantine), Leviathan (Scott Westerfeld), The Left Hand of God (Paul Hoffman), A Game of Thrones (George Martin), Anno Dracula (Kim Newman), Storm Front (Jim Butcher).

\section{Romance}

Beyond Sunrise (Candice Proctor), The Unwanted Wife (Natasha Anders), The Other Guy's Bride (Connie Brockway), A Daring Liaison (Gail Ranstrom), Ain't She Sweet (Susan Elizabeth Philip), A Bend in the Road (Nicholas Sparks), Lover Unexpected (Brindle Chase), Rose (Leigh Greenwood), Where Dreams are Born (M. L. Buchman), Gabriel's Inferno (Sylvain Reynard).

\section{Crime}

The Stranger You Know (Jane Casey), Medicus and the Disappearing Dancing Girls (Ruth Downie), The Silkworm (Robert Galbraith aka J. K. Rowling), 
Naked in Death (J. D. Robb), The Rembrandt Secret (Alex Connor), Sanctus (Simon Toyne), The Book of Secrets (Tom Harper), Kill Alex Cross (James Patterson), Tell no One (Harlan Coben), The Bone Collector (Jeffery Deaver).

Spanish: 3,717,807 words

Fantasy

Hijos del clan rojo (Elia Barceló), Hojas de dedalera (Victoria Álvarez), La resistencia (Laura Gallego), Los tres secretos del samurái (Blanca Álvarez González), El fin de los sueños (Gabriella Campbell \& Jose Antonio Cotrina), El espíritu del mago (Javier Negrete), Rihla (Juan Miguel Aguilera), La caza del nigromante (Antonio Martin Morales), La cosecha de Samhein (José Antonio Cotrina), El círculo de Koria (Bel Atreides).

\section{Romance}

Las ranas también se enamoran (Megan Maxwell), El sacrificio del verdugo (Noelia Amarillo), El libro de jade (Lena Valenti), Regálame Paris (Olivia Ardey), Buenos días, princesa (Blue Jeans), Lo inevitable del amor (Nuria Roca \& Juan del Val), Ojalá estuvieras aquí (Francesc Miralles), El viaje de Marcos (Oscar Hernández), La protegida Wittman (Iván Hernández), A fuego lento (Anna Casanovas).

Crime

El guardián invisible (Dolores Redondo), Las niñas perdidas (Cristina Fallarás), Ritos de muerte (Alicia Giménez Bartlett), Entre dos aguas (Rosa Ribas), Y punto (Mercedes Castro), El péndulo (Rafael Ábalos), Expediente Barcelona (Francisco González), El misterio de la Casa Aranda (Jerónimo Tristante), El verano de los juguetes muertos (Toni Hill), La niebla y la doncella (Lorenzo Silva).

\section{APPENDIX B}

\section{Semantic categories and their realization in the English and Spanish corpora}

English data

\section{SPEECH (133 types/19,865 tokens)}

say (12,979), ask (2,495), tell (671), reply (578), answer (224), repeat (205), explain (190), agree (176), demand (175), announce (150), admit (132), suggest (103), insist (94), remind (74), order (72), correct (67), warn (65), observe (64), respond (63), protest (61), declare (58), assure (54), lie (51), command (50), promise (50), comment (45), retort (44), swear (44), prompt (40), complain (37), 
counter (36), echo (35), inform (33), urge (33), state (28), remark (25), persist (22), plead (22), read (22), confess (20), greet (20), inquire (19), confirm (18), tease (18), clarify (17), concede (16), speak (16), acknowledge (15), instruct (15), reassure (15), venture (15), object (14), beg (13), challenge (12), dismiss (12), admonish (11), invite (11), query (11), advise (10), chide (10), report (10), vow (10), apologize (9), volunteer (9), caution (8), confide (8), taunt (8), amend (7), argue (7), contradict (6), allow (5), curse (5), scold (5), threaten (5), translate (5), accuse (4), address (4), hail (4), note (4), predict (4), soothe (4), affirm (3), coax (3), concur (3), direct (3), implore (3), name (3), pronounce (3), quote (3), sympathize (3), approve (2), assert (2), cajole (2), deny (2), disagree (2), elaborate (2), encourage (2), enquire (2), negate (2), opine (2), qualify (2), question (2), summarize (2), toast (2), acquiesce (1), commiserate (1), counterorder (1), defend (1), emphasise (1), entreat (1), excuse (1), half-ask (1), hedge (1), hint (1), improvise (1), introduce (1), lament (1), persevere (1), placate (1), pray (1), preempt (1), propose (1), rebuke (1), refute (1), reiterate (1), rephrase (1), reproach (1), request (1), reveal (1), rib (1), risk (1), spell (1), talk (1), transmit (1), utter (1)

\section{SPEECH manner-human (72 types/2,786 tokens)}

whisper (643), shout (350), call (312), mutter (296), murmur (274), cry (113), hiss (94), scream (73), exclaim (70), blurt (61), yell (60), mumble (58), grumble (43), groan (26), moan (24), rasp (22), drawl (18), stammer (18), intone (17), shriek (16), sing (16), scoff (13), sputter (12), wail (11), joke (10), whimper (9), croon (8), quip (8), recite (8), splutter (8), proclaim (7), demur (6), mock (6), babble (5), chant (5), enthuse (5), whine (5), half-whisper (4), holler (4), bluster (3), chorus (3), husk (3), shrill (3), stutter (3), brag (2), dictate (2), falter (2), grouse (2), gush (2), jest (2), lecture (2), slur (2), bawl (1), blether (1), blunder (1), boast (1), chatter (1), count (1), ejaculate (1), enunciate (1), gabble (1), incant (1), itemise (1), keen (1), mimic (1), rant (1), scorn (1), sing-song (1), stage-whisper (1), wheedle (1), whoop (1)

\section{SPEECH manner-animal (21 types/343 tokens)}

growl (98), snarl (45), bark (43), croak (28), roar (27), bellow (23), purr (21), grunt (18), coo (12), howl (8), crow (3), drone (3), squawk (3), squeal (3), yelp (3), cackle (1), caw (1), half-growl (1), hoot (1), parrot (1), trill (1)

\section{SPEECH manner-animate (12 types/58 tokens)}

grit (8), thunder (7), boom (6), chime (6), screech (4), grate (3), pipe (3), rumble (3), squeak (3), burble (1), trumpet (1) 


\section{ACTIVITY (184 types/1,937 tokens)}

add (283), continue (255), snap (193), begin (166), go on (94), point out (90), interrupt (83), finish (66), offer (66), nod (39), put in (37), shrug (35), shake head (34), start (25), conclude (24), pause (20), cut in (18), point to/at (18), interject (16), hold + prep (15), turn + prep (14), lean (13), wave (10), return (9), stop (9), grind out (7), maintain (7), lift (6), reach (6), supply (6), break in (5), come + prep (5), cut off (5), throw (5), check (4), drop (4), gesture (4), keep (4), settle (4), 4), trail (off) (4), contribute (3), extend hand (3), get out (3), head (3), insert (3), intercede (3), intervene (3), lower (3), pull (3), push (3), raise (3), step (3), stand (3), tuck (3), use (3), breach (2), break off (2), cut across (2), drop voice (2), find voice (2), get up (2), grab (2), hurl (2), hurry (2), inject (2), kick (2), leap (2), make (2), place (2), rise (2), run (2), rub + fingers (2), shove (2), sip (2), stick (2), stumble (2), sweep (2), take (2), tap (2), bolt (1), bow (1), break stalemate (1), break silence (1), bring (1), brush (1), bury (1), change subject (1), change track (1), chip in (1), clamp down (1), clap (1), clasp (1), clip out (1), cock head (1), complete (1), cradle (1), cross arms (1), cuff (1), cup hands (1), cut to the point (1), dash out (1), disintegrate (1), double-check (1), do (1), duck (1), emerge (1), engulf (1), face (1), fidget (1), fill in (1), flag (1), flash out (1), flick (1), flip over (1), flood (1), flourish (1), fly (1), follow (1), freeze (1), fuss (1), give a push (1), give back (1), give a shrug (1), go (1), get stuck (1), grasp arm (1), grip (1), grope (1), gut out (1), half rise (1), help (1), hug (1), indicate (1), intercept (1), itch (1), jerk (1), jump (1), kneel (1), knock back (1), lay (1), lead one's way (1), leave (1), lose balance (1), mimic gesture (1), move (1), nibble (1), nudge (1), overflow (1), pass (1), play (1), poke (1), pound (1), pour (1), press oneself (1), produce (1), put (1), rap (1), reinforce (1), rejoin (1), relent (1), resort (1), rest (1), resume (1), rush (1), save (1), scramble (1), scroll (1), search (1), seize (1), set down (1), shoot forward (1), shudder (1), silence (1), sit up (1), slam (1), slap (1), slide (1), slip out (1), slouch (1), slump (1), smack (1), snatch (1), spin around (1), spoil (1), spur horse (1), squeeze (1), stagger (1), straighten up (1), stretch (1), summon (1), supplement (1), sway (1), swing (1), swipe (1), swoop in (1), take opportunity (1), tighten (1), tilt (1), tip (1), toss (1), thrust (1), thumb (1), wade (1), waggle (1), wake (1), walk away (1), waltz (1), warm (1), whisk (1), wrap (1), whip (1), withdraw (1)

\section{ACTIVITY face (85 types/523 tokens)}

breathe (82), gasp (46), sigh (42), laugh (37), spit (36), smile (23), snort (19), sneer (16), pant (14), glance (13), choke (12), look + prep (12), sob (11), wheeze (11), grin (10), mouth (8), chuckle (7), giggle (7), clear throat (6), swallow (6), sniff (5), weep (5), cough (3), frown (3), gurgle (3), huff (3), meet eyes/gaze (3), narrow eyes (3), roll eyes (3), blow (2), clench teeth (2), cluck (2), drop gaze/eyes (2), half-laugh (2), hum (2), leer (2), shoot look/glare (2), take a breath (2), beam (1), bite out (1), blink (1), bore (1), catch eye (1), catch up breath (1), chortle (1), clack (1), cock eyebrow (1), come out (breath) (1), consult (1), deadpan (1), 
drag gaze (1), draw breath (1), draw out (1), drool (1), examine (1), eye (1), find (eyes) (1), flare (eyes) (1), follow glance (1), gargle (1), gaze (1), gentle (smile) (1), give a hmph (1), give a smile (1), gawp (1), glare (1), go (gaze) (1), gobble (1), grimace (1), grind one's teeth (1), half-sob (1), hiccup (1), hover (eyebrows) (1), inhale (1), jut out chin (1), let out breath (1), maintain smile (1), make a face (1), open mouth (1), press lips (1), raise chin (1), run gaze (1), scan (1), shut eyes (1), skirt (eyes) (1), smirk (1), snicker (1), sniffle (1), snuffle (1), soften (face) (1), spread (smile) (1), squint (1), stare (1), study (1), take a gulp of (1), turn eyes (1), tsk (1), watch (1), widen eyes (1), wince (1)

\section{ACTIVITY confrontation (8 types/43 tokens)}

shoot + prep (28), prod (7), parry (2), soldier on (2), defend (1), forestall (1), lay into (1), provoke (1)

ACTIVITY human force (4 types/59 tokens)

manage (28), press (15), try (15), make do (1)

\section{EMOTION (24 types/89 tokens)}

explode (15), hesitate (13), burst (9), seethe (9), fume (5), blush (4), flare (4), marvel (4), blaze (3), storm (3), surprise (3), frustrate (2), rage (2), shock (2), startle (2), bother (1), brighten (1), calm down (1), compose (1), despair (1), feel compunction (1), flush (1), like (1), pale (1)

\section{Cognition (15 types/78 tokens)}

muse (40), wonder (14), decide (5), reflect (4), guess (3), deduce (2), know (2), recall (2), calculate (1), choose (1), enlighten (1), ignore (1), make sense (1), remember (1), think (1)

\section{PERCEPTION (1 type/1 token)}

feel (19)

\section{PERCEPTION hearing (97 types/382 tokens)}

hear (85), say (54), come (36), call (31), ask (12), whisper (9), shout (8), ring (6), reply (6), answer (5), demand (5), trail (5), continue (4), interrupt (4), rumble (4), announce (3), boom (3), cut (in) (3), echo (3), float (3), bark (2), bellow (2), break (2), command (2), crack (2), crackle (2), drop (2), growl (2), intone (2), murmur (2), offer (2), snap (2), sound (2), squeak (2), take + tone (2), tremble (2), add (1), assure (1), babble (1), catch (1), chirp (1), clatter (1), complain (1), coo (1), correct (1), creak (1), creep (1), croak (1), crow (1), cry (1), curse (1), declare (1), 
deepen (1), distract (1), drip (1), explain (1), fade (1), falter (1), hiss (1), holler (1), interject (1), intrude (1), jerk (1), jump (1), lower (1), moan (1), overhear (1), peter off (1), pipe up (1), plead (1), prompt (1), put in (1), quiet (1), quiver (1), repeat (1), respond (1), roar (1), rustle (1), scold (1), send (1), shake (1), sing (1), snarl (1), speak (1), spit (1), squawk (1), startle (1), supply (1), swear (1), taper (1), tease (1), thicken (1), urge (1), warn (1), wheedle (1), wheeze (1), yell (1)

\section{PERCEPTION sight (2 types/4 tokens)}

notice (3), glimpse (1)

\section{AuX (36 types/235 tokens)}

be (84), manage (24), start (14), try (14), sound (11), seem (10), can (9), begin (8), find oneself (5), force (5), have (5), want (5), hasten (4), keep (4), make (4), look (3), come (2), decide (2), demand (2), let (2), remember (2), strive (2), appear (1), ask (1), attempt (1), bother (1), compel (1), continue (1), dare (1), feel (1), grow (1), need (1), sit (1), stop (1), struggle (1), used to (1)

Spanish data

\section{SPEECH (229 types/18,167 tokens)}

decir $(6,848)$, preguntar $(3,386)$, responder $(1,042)$, contestar (830), comentar (434), explicar (377), repetir (280), afirmar (257), insistir (248), ordenar (242), replicar (206), pedir (189), asegurar (181), advertir (164), asentir (158), protestar (133), confesar (132), reconocer (132), anunciar (128), aclarar (120), inquirir (100), sugerir (99), admitir (88), suplicar (82), saludar (78), exigir (77), hablar (75), proponer (75), informar (72), mentir (68), declarar (64), aceptar (62), corregir (61), recordar (51), disculpar(se) (49), rogar (49), quejarse (46), confirmar (43), opinar (43), recriminar (41), aconsejar (36), lamentar(se) (36), excusarse (35), leer (34), observar (34), tranquilizar (32), rebatir (31), aseverar (30), conceder (30), matizar (30), animar (29), puntualizar (28), despedir(se) (24), alegar (23), regañar (23), amenazar (20), avisar (20), reprochar (20), apremiar (19), expresar (19), negar(se) (19), presentar(se) (18), pronunciar (18), apostillar (17), instar (17), invitar (17), corroborar (16), objetar (16), aventurar (15), callarse (15), insinuar (15), recomendar (15), cuestionar (14), interrogar (14), argumentar (13), desafiar (13), rechazar (13), resumir (13), agradecer (12), contar (12), implorar (12), prometer (12), solicitar (12), justificar(se) (11), rectificar (11), reñir (11), sincerarse (11), acusar (10), precisar (10), reclamar (10), traducir (10), comunicar (9), consultar (9), desear (9), interpelar (9), reiterar (9), reprender (9), revelar (9), consolar (8), convenir (8), contradecir (7), enumerar (7), juzgar (7), constatar (6), destacar (6), exponer (6), indagar (6), maldecir (6), refutar (6), apoyar (5), aprobar (5), hacer pregunta (5), jurar (5), recapitular (5), urgir (5), acatar (4), 
brindar (4), ceder (4), concretar (4), desvelar (4), enunciar (4), especificar (4), felicitar (4), formular (4), glosar (4), manifestar (4), proferir (4), pronosticar (4), provocar (4), retar (4), sentenciar (4), acordar (3), adular (3), calmarse (3), citar (3), coincidir (3), condescender (3), desestimar (3), garantizar (3), hacer notar (3), incidir (3), incitar (3), llamar la atención (3), narrar (3), oponer(se) (3), ratificar (3), rehusar (3), secundar (3), aducir (2), alabar (2), alentar (2), articular (2), augurar (2), censurar (2), conminar (2), declinar (2), denegar (2), estar de acuerdo (2), instruir (2), insultar (2), mostrarse de acuerdo (2), presagiar (2), reafirmar (2), reconvenir (2), requerir (2), simplificar (2), teorizar (2), vaticinar (2), abroncar (1), acallar (1), acceder (1), aleccionar (1), aludir (1), amonestar (1), aplacar (1), asumir (1), blasfemar (1), celebrar (1), comprobar (1), comprometerse (1), confiar (1), confortar (1), corresponder (1), criticar (1), dar indicaciones (1), dar permiso (1), dejar claro (1), desahogarse (1), descararse (1), describir (1), desechar (1), desmentir (1), determinar (1), discutir (1), disponer (1), encomendar (1), enjuiciar (1), enmudecer (1), exculparse (1), explicitar (1), guiar (1), halagar (1), hacer comentario (1), hacer confesión (1), hacer petición (1), imprecar (1), inventar (1), investigar (1), llamar (1), nombrar (1), notificar (1), ofender (1), planificar (1), predecir (1), presumir (1), profetizar (1), prohibir (1), redundar (1), reescribir (1), refrendar (1), reivindicar (1), relatar (1), renegar (1), retractarse (1), sancionar (1), silenciar (1), sintetizar (1), sosegar (1), tentar (1)

\section{SPEECH manner-human (74 types/4,479 tokens)}

susurrar (1,040), gritar (771), murmurar (734), exclamar (603), musitar (246), gruñir (109), sentenciar (86), mascullar (84), llamar (80), sisear (63), bromear (59), gemir (55), mofarse (47), balbucear (42), ironizar (38), chillar (33), burlarse (29), farfullar (26), increpar (25), titubear (24), guasearse (23), recalcar (23), tartamudear (19), cuchichear (18), refunfuñar (18), rezongar (18), recitar (17), cantar (13), canturrear (11), chistar (9), clamar (9), proclamar (9), barbotar (7), gimotear (7), vociferar (7), dictaminar (6), silabear (6), balbucir (5), jactarse (5), decretar (4), deletrear (3), enfatizar (3), exagerar (3), renegar (3), vocear (3), bisbisear (2), corear (2), declamar (2), dictar (2), dramatizar (2), exhortar (2), retrucar (2), aclamar (1), alardear (1), arengar (1), azuzar (1), cachondearse (1), charlar (1), delirar (1), discursar (1), disertar (1), entonar (1), impostar (1), jipiar (1), murmujear (1), parlotear (1), pregonar (1), recochinearse (1), relativizar (1), remarcar (1), remugar (1), satirizar (1), tartajear (1), vitorear (1)

\section{SPEECH manner-animal (12 types/98 tokens)}

bramar (25), rugir (25), aullar (19), ronronear (10), graznar (7), gorjear (3), ladrar (3), cloquear (2), dar un bramido (1), gallear (1), urajear (1), zumbar (1)

\section{SPEECH manner-inanimate (2 types/12 tokens)}

tronar (9), restallar (3) 


\section{ACTIVITY (343 types/4,326 tokens)}

añadir (572), reponer (261), señalar (207), proseguir (190), interrumpir(se) (184), continuar (182), intervenir (155), concluir (123), indicar (121), apuntar (118), espetar (107), soltar (83), cortar (78), tomar (48), ofrecer(se) (46), detener(se) (45), dar + NP (43), levantar (42), acercar(se) (40), seguir (39), comenzar (37), terminar (35), dirigirse a (34), poner (34), empezar (33), inclinar(se) (33), apretar (31), volver(se) (31), coger (30), terciar (30), encogerse de hombros (29), alzar (27), saltar (27), hacer pausa (26), atajar (26), abrazar(se) (24), acariciar (24), besar (22), cambiar (22), girarse (22), negar con cabeza/gesto/mueca (20), apartar(se) (19), adelantarse (18), aplaudir (18), bajar (18), lanzar usu. OD speech related (17), colocar(se) (14), retornar (14), salir (14), abrir (13), completar (13), pasar(se) (13), agarrar (12), temblar (12), apoyar (11), empujar (11), llevar(se) usu. manos (11), mover (11), sacudir (11), tirar (11), deslizar (10), echar + NP (10), escapar(se) (10), frenar (10), golpear (10), hacer gesto (10), retomar (10), buscar (9), cruzar (9), dejar (9), dejar caer (9), imitar (9), rozar (9), tender (9), disimular (8), guardar (8), improvisar (8), menear (8), quebrarse usu. voz (8), zanjar (8), agregar (7), ayudar (7), estremecerse (7), romper (7), sacar (7), sentarse (7), tantear (7), zarandear (7), agitar(se) (6), entrar (6), gesticular (6), hacer (6), incorporarse (6), quitar(se) (6), retirar(se) (6), rumiar (6), tocar (6), acompañar (5), agachar(se) (5), anotar (5), arrancar (5), caminar (5), esperar (5), introducir (5), mostrar (5), reaccionar (5), revolver(se) (5), rodear (5), tornar (5), acabar (4), arrojar (4), descender (4), descolgar (4), devolver (4), encontrar (4), entregar (4), finalizar (4), frotar (4), hundir(se) (4), mecer (4), morder (4), perder (4), recular (4), separar(se) (4), acomodar(se) (3), alargar (3), anticipar (3), aparecer (3), beber (3), cerrar (3), elegir (3), escribir (3), fingir (3), jugar (3), lamer (3), parar(se) (3), prorrumpir (3), recibir (3), remover(se) (3), restregar(se) (3), secarse (3), subrayar (3), usar (3), zafarse (3), abarcar (2), adoptar (2), apostar (2), aumentar (2), avanzar (2), cabecear (2), cernerse (2), chasquear usu. dedos (2), clavar(se) (2), colar (2), colgar(se) (2), contener(se) (2), controlar (2), cubrir (2), depositar (2), despertar(se) (2), devorar (2), echar(se) a + inf (2), elevar (2), embestir (2), encarar (2), enderezar(se) (2), entrelazar (2), estirar(se) (2), estrechar (2), evitar (2), imponer(se) (2), impulsar (2), intercambiar (2), interponer(se) (2), inundar (2), ir (2), juntar (2), limpiar (2), llegar (2), llenar (2), marcar (2), masticar palabras (2), palmear (2), picar (2), plantar(se) (2), pulsar (2), quedarse en silencio/con palabra en boca (2), reclinarse (2), recobrar (2), recoger (2), recomponerse (2), recuperar (2), rehacerse (2), remachar (2), repasar (2), resistirse (2), hacerse un nudo en garganta (2), retroceder (2), simular (2), sujetar(se) (2), taparse (2), teñir (2), variar (2), abalanzarse (1), abordar (1), abrochar(se) (1), activarse (1), acudir (1), acunar (1), adherirse (1), aferrar (1), afrontar (1), aguardar (1), ahuecar (1), alisar (1), alumbrar (1), andarse con ceremonias (1), apaciguar (1), apagar (1), aportar (1), apresurar (1), aproximar(se) (1), apuntillar (1), arreglar(se) (1), arrimar (1), ascender (1), asentir (1), asomarse (1), atascarse (1), atender (1), atravesar (1), atropellar (1), auxiliar (1), avenirse (1), blandir (1), brotar (1), 
caber en si (1), caer (1), castañetear (1), cejar (1), ceñirse (1), cerrarse en banda (1), cojear (1), correr (1), crecer (1), dar la razón (1), darse la vuelta (1), dedicar (1), derrumbarse (1), desatarse (1), desbordar (1), descubrirse (1), descubrir (cartas) (1), desgarrarse (1), desmoronarse (1), desplegar (1), desplomarse (1), destaparse (1), dibujar (1), doblar (1), ejercer (1), eludir (1), embalarse (1), embarcarse (1), encizañar (1), endurecer (1), enfriar (1), enrollarse (1), enseñar (1), entrar al trapo (1), entrometerse (1), enumerar con dedos (1), envainar (1), enviar (1), espontanearse (1), estrangular (1), extender (1), extraer (1), firmar (1), ir al grano (1), ir al tema (1), hacer señal (1), hacer como que + clause (1), hinchar pecho (1), hacerse a un lado (1), hacerse un todo (1), helar (1), hincar (1), humedecer (1), hurgar (1), incluir (1), inhibirse (1), iniciar (1), inmiscuirse (1), llamar a la puerta (1), mantener (1), masajear (1), materializarse (1), meter baza (1), meterse (1), mimetizarse (1), mordisquear (1), nublar (1), obedecer (1), obrar (en consecuencia) (1), obsequiar (1), omitir (1), organizar (1), paralizar (1), pegar (1), pellizcar (1), penetrar (1), persignarse (1), plegarse (1), preparar (1), provocar (1), proyectar (1), ponerse de puntillas (1), posar (1), rascar(se) (1), reaparecer (1), rebuscar (1), realizar gesto (1), reclamar (1), reconstruir (1), recorrer (1), regresar (1), rehuir (1), remedar (1), renovar (1), repanchigarse (1), resbalar (1), rescatar (1), resolver (1), responder con un gesto (1), restar importancia (1), retorcer (1), retener (1), reunir (1), rezumar (1), simultanear (1), sobreactuar (1), sondear (1), sopesar (1), sortear (1), suavizar (1), subir (1), succionar (1), sucumbir (1), sumarse (1), surgir (1), sustituir (1), teclear (1), tensar (1), trabarse (1), traslucir (1), trazar un gesto (1), unirse (1), vaciar (1), verter (1), volar (1), volver en si (1)

\section{ACTIVITY face (140 types/1,329 tokens)}

sonreír (304), mirar (191), reír (137), suspirar (119), jadear (68), continuar (67), alzar + part of face (30), sollozar (29), escupir (25), resoplar (25), tragar saliva (17), bufar (15), tomar aliento/aire (14), fruncir (13), hacer mueca/gesto cara (13), levantar part of face (13), morderse usu. labios (10), exhalar (9), respirar (hondo) (9), soltar risa/suspiro (9), carcajearse (8), aclarar(se) voz/garganta (7), arquear cejas (7), carraspear (7), guiñar ojo (7), llorar (7), abrir ojos/boca (6), cerrar ojos (6), inspirar (6), arrugar entrecejo/nariz (5), bostezar (5), clavar mirada/pupilas (5), echar vistazo/mirada (5), entornar ojos (5), observar (5), poner + parte cara/gesto (5), rebufar (5), silbar (5), apartar mirada (4), bajar vista/mirada/ojos (4), brillar ojos (4), chasquear lengua (4), inspeccionar (4), buscar con la mirada (3), dedicar sonrisa/mirada (3), desviar mirada (3), dibujar sonrisa/gesto/mueca (3), dirigir mirada/ojos (3), inhalar (3), oscurecerse mirada/ojos (3), temblar parte cara (3), achicar ojos (2), agrandar ojos (2), ahogar risa (2), apretar boca/dientes (2), coger aire (2), componer gesto/expresión (2), deletrear con mano (2), esbozar sonrisa (2), estudiar (2), iluminar mirada (2), lanzar guiño (2), olisquear (2), pasar lengua por labios (2), repasar con ojos (2), reprender con mirada/ojos (2), resollar (2), saborear (2), sorber (2), torcerse (2), toser (2), acentuar sonrisa (1), acompañar con risa/sonrisa (1), agachar la mirada (1), ahogarse (1), amagar gesto (1), 
aspirar (1), atragantarse (1), babear (1), boquear (1), cambiar semblante (1), cegar (1), chispear ojos (1), consultar (1), contemplar (1), contener aliento (1), cruzar mirada (1), demostrar en rostro (1), despegar labios (1), destellar ojos (1), dulcificar rostro (1), elevar labios (1), enarcar ceja(s) (1), endurecer mirada (1), ensanchar sonrisa (1), enseñar los dientes (1), ensombrecer mirada (1), entrecerrar ojos (1), escaparse risotada (1), escrutar (1), esforzar ojos (1), espirar (1), esquivar mirada (1), estallar en carcajada (1), examinar (1), expresar ojos (1), expulsar risa (1), fijarse (1), fijar la mirada (1), fulminar con mirada (1), gritar gestos (1), hacer grande sonrisa (1), hacer chiribitas ojos (1), hipar (1), ir (mirada) (1), implorar (pupilas) (1), improvisar mohín (1), intensificar sonrisa (1), interrogar con mirada (1), lanzar risa (1), liberar carcajada (1), lloriquear (1), mantener mirada (1), mostrar sonrisa (1), mover mandíbula (1), oler (1), paladear (1), parpadear (1), pestañear (1), recorrer con ojos (1), reflejar rostro (1), rehuir mirada (1), relajar gesto (1), relamerse (1), relampaguear en ojos (1), remover rasgos (1), revisar (1), seguir con los ojos (1), taladrar con mirada (1), teñir ojos (1), venirse abajo sonrisa (1), reprimir sonrisa (1)

\section{ACTIVITY confrontation (27 types/98 tokens)}

defender(se) (33), disparar (8), rendirse (8), atacar (7), contraatacar (7), rematar (7), claudicar (4), volver a la carga (3), asaltar (2), picar (2), repeler (2), abrir fuego (1), armarse de valor (1), arrojar el guante (1), devolver el palo (1), escudarse (1), forcejear (1), herir (1), luchar (1), mediar (1), morder la presa (1), pelear (1), pinchar (1), ponerse a la defensiva (1), someterse (1), pasar a la ofensiva (1)

\section{ACTIVITY human-force (6 types/9 tokens)}

intentar (2), presionar (2), resistirse (2), conseguir (1), forzar (1), hacer esfuer$\operatorname{zos}(1)$

\section{EMOTION (59 types/225 tokens)}

sorprender(se) (31), extrañar(se) (27), estallar (21), interesarse (20), asombrarse (15), alarmarse (7), explotar (6), impacientarse (6), encresparse (5), escandalizarse (5), entusiasmarse (4), inquietarse (4), preocuparse (4), rebelarse (4), admirar(se) (3), horrorizarse (3), ruborizarse (3), sobresaltarse (3), animarse (2), asustarse (2), desconcertar(se) (2), desconfiar (2), desesperarse (2), despreciar (2), doler (2), empecinarse (2), enfadarse (2), indignarse (2), recrearse (2), resignarse (2), sonrojarse (2), agobiarse (1), aguantar (1), alborotarse (1), alterarse (1), arriesgar (1), avergonzarse (1), cabrearse (1), calmarse (1), confiar (1), conformarse (1), congratularse (1), conmoverse (1), desear (1), divertir (1), empeñarse (1), enojarse (1), exaltarse (1), humillarse (1), molestarse (1), montar en cólera (1), ofenderse (1), rebotarse (1), recelar (1), serenarse (1), sobrecogerse (1), soportar (1), temer (1), tensarse (1) 


\section{Cognition (50 types/324 tokens)}

decidir (47), recordar (39), dudar (34), suponer (24), comprender (16), adivinar (15), deducir (13), meditar (12), reflexionar (12), intuir (9), ocurrir (9), pensar (9), calcular (6), curiosear (6), darse cuenta (5), ignorar (5), concluir (4), conjeturar (4), inferir (4), razonar (4), acordarse (3), elucubrar (3), especular (3), imaginar(se) (3), resolver (3), arrepentirse (2), denotar (2), descubrir (2), entender (2), recapacitar (2), saber (2), sospechar (2), volver en si (2), cavilar (1), colegir (1), considerar (1), convencerse (1), dar crédito (1), darse cuenta (1), dar por supuesto (1), eligir (1), evocar (1), implicar (1), interpretar (1), parecer (1), perder el hilo de pensamiento (1), presuponer (1), tener claro (1), tener una idea (1), tomar una decisión (1)

\section{PERCEPTION (6 types/15 tokens)}

notar (6), sentir (4), apreciar (2), advertir (1), parecer (1), percibir (1)

\section{PERCEPTION hearing (112 types/446 tokens)}

oir (89), decir (69), escuchar (52), gritar (16), susurrar (16), preguntar (11), sonar (11), retumbar (10), sorprender (9), temblar (9), llegar (8), quebrarse (8), resonar (6), contestar (5), responder (5), ordenar (4), regresar (4), destilar (3), exclamar (3), salir (3), sisear (3), tronar (3), continuar (2), cortar (2), detectar (2), exigir (2), interrumpir (2), intervenir (2), llamar (2), musitar (2), proclamar (2), proseguir (2), reconocer (2), rodear (2), romper (2), rugir (2), sacar (2), sobresaltarse (2), variar (2), ahogarse (1), alertar (1), alzarse (1), amenazar (1), añadir (1), anunciar (1), aproximarse (1), asegurar (1), aseverar (1), atender (1), atormentar (1), atravesar (1), atronar (1), ausentarse (1), avisar (1), bajar (1), balbucear (1), bramar (1), burlarse (1), clamar (1), colgarse (1), delatar (1), demandar (1), descender (1), desgarrarse (1), desmoronarse (1), disculparse (1), distraer (1), dulcificarse (1), elevarse (1), entrecortarse (1), enunciar (1), estallar (1), explicar (1), hablar (1), hacer eco (1), hacer que (1), impacientarse (1), imperar (1), implorar (1), imponer (1), inmiscuirse (1), inquirir (1), insistir (1), irradiar (1), irrumpir (1), llevar (1), mancharse (1), molestar (1), murmurar (1), oscurecer (1), pedir (1), presentarse (1), protestar (1), poner (1), rebotar (1), recitar (1), recorrer (1), reflejar (1), repetir (1), reponer (1), retornar (1), rezumar (1), rozar (1), sentir (1), seguir (1), suavizarse (1), sugerir (1), surgir (1), teñirse (1), traslucir (1), vacilar (1), volver (1)

\section{PERCEPTION sight (3 types/7 tokens)}

ver (4), apreciar (2), reconocer (1)

\section{PERCEPTION touch (7 types/13 tokens)}

sentir (6), notar (2), cortar (1), doler (1), escocer (1), quemar (1), recorrer (1) 


\section{AuX (91 types/1,164 tokens)}

seguir (114), volver (92), querer (83), comenzar (72), ser (72), apresurarse (54), poder (50), intentar (44), empezar (38), tener (33), continuar (31), estar (31), lograr (25), parecer (25), atreverse (24), acertar (22), conseguir (22), tratar (22), limitarse (20), dejar (17), echarse (17), decidir (14), poner(se) (13), mostrarse (11), terminar (11), alcanzar (10), exigir (10), hacer (10), quedarse (9), tardar (9), acabar (8), creer (8), obligar(se) (8), sonar (8), ocurrírsele (7), sentir(se) (6), arriesgarse (5), costar(le) (5), esforzarse (5), fingir (5), hacerse (5), ir (5), tornarse (5), volverse (5), soler (4), aprovechar (3), haber (3), llegar (3), optar (3), preferir (3), quedar (3), saber (3), salir (3), animarse (2), evitar (2), llevar(le) (2), omitir (2), permitir(se) (2), procurar (2), romper (2), simular (2), acceder (1), acordarse (1), anticiparse (1), aprestarse (1), aventurarse (1), dar tiempo (1), darse el gusto (1), desear (1), dignarse (1), disponerse (1), dudar (1), encantar (1), inclinarse (1), juzgar (1), levantase (1), necesitar (1), odiar (1), osar (1), pasar (1), pensar (1), permanecer (1), precipitarse (1), pretender (1), proceder (1), provocar (1), resistirse (1), resultar (1), soportar (1), tirar (1), traducirse (1)

\section{REFERENCES}

Buchstaller, Isabelle \& Ingrid van Alphen (eds.). 2012. Quotatives: Cross-linguistic and crossdisciplinary perspectives. Amsterdam: John Benjamins.

Caballero, Rosario. 2015. Reconstructing speech events: Comparing English and Spanish. Linguistics 53.6, 1391-1431.

Caballero, Rosario \& Carita Paradis. 2015. Making sense of sensory perceptions across languages and cultures. Functions of Language 22.1, 1-19.

Clark, Herbert \& Richard J. Gerrig. 1990. Quotations as demonstrations. Language 66.4, 764-805.

Contreras, Hernán. 1988. Los verbos dialogales en inglés y en castellano. Revista de Lingüística Teórica y Aplicada 26, 23-27.

Coulmas, Florian (ed.). 1986. Direct and indirect speech. Berlin: Mouton de Gruyter.

Cruse, Alan. 2002. The construal of sense boundaries. Revue de sémantique et pragmatique 12, 37-52.

De Roeck, Marijke. 1994. A functional typology of speech reports. In Elisabeth Engberg-Pedersen, Lisbeth Falster Jakobsen \& Lone Schack Rasmussen (eds.), Function and expression in functional grammar, 331-351. Berlin: Mouton de Gruyter.

Dirven, René, Louis Goossens, Yvan Putseys \& Emma Vorlat. 1982. The scene of linguistic action and its perspectivization by speak, talk, say and tell. Amsterdam: John Benjamins.

Faber, Pamela B. \& Ricardo Mairal Usón. 1999. Constructing a lexicon of English verbs. Berlin \& New York: Mouton de Gruyter.

Fagard, Benjamin, Jordan Zlatev, Anetta Kopecka, Massimo Cerruti \& Johan Blomberg. 2016. The expression of motion events: A quantitative study of six typologically varied languages. Proceedings of the 39th Annual Meeting of the Berkeley Linguistics Society (BLS 39), 364-379.

Filipović, Luna. 2007. Talking about motion: A crosslinguistic investigation of lexicalisation patterns. Amsterdam: John Benjamins.

Gärdenfors, Peter. 2014. The geometry of meaning: Semantics based on conceptual spaces. Cambridge, MA \& London: MIT Press.

Goldberg, Adele E. 1995. Constructions: A Construction Grammar approach to argument structure. Chicago, IL: The University of Chicago Press.

Goossens, Louis. 1990. Metaphtonymy: The interaction of metaphor and metonymy in expressions for linguistic action. Cognitive Linguistics 1.3, 323-340.

Güldemann, Tom \& Manfred von Roncador (eds.). 2002. Reported discourse: A meeting ground for different linguistic domains. Amsterdam: John Benjamins.

Holt, Elizabeth \& Rebecca Clift (eds.). 2007. Reporting talk: Reported speech in interaction. Cambridge: Cambridge University Press. 
Jones, Steven, M. Lynne Murphy, Carita Paradis \& Caroline Willners. 2012. Antonyms in English: Construals, constructions and canonicity. Cambridge: Cambridge University Press.

Kissine, Mikhail. 2010. Metaphorical projection, subjectification and English speech act verbs. Folia Linguistica 44.2, 339-370.

Klamer, Marian. 2000. How report verbs become quote markers and complementisers. Lingua 110, 69-98.

Koptjevskaja-Tamm, Maria. 2015. Semantic typology. In Ewa Dąbrowska \& Dagmar Divjak (eds.), Handbook of cognitive linguistics, 453-472. Berlin: Mouton de Gruyter.

Lehrer, Adrienne. 1988. Checklist for verbs of speaking. Acta Linguistica Hungarica 38.1-4, 143-161.

Levin, Beth. 1993. English verb classes and alternations. Chicago, IL: The University of Chicago Press.

Levinson, Stephen C. \& David P. Wilkins. 2006. Grammars of space: Explorations in cognitive diversity. Cambridge: Cambridge University Press.

Lucy, John A. (ed.). 1993. Reflexive language: Reported speech and metapragmatics. Cambridge: Cambridge University Press.

Majid, Asifa \& Stephen C. Levinson. 2011. The senses in language and culture. Senses \& Society 6.1, 5-18.

Maldonado, Concepción. 1991. Discurso directo y discurso indirecto. Madrid: Taurus Universitaria.

Martínez Vázquez, Montserrat. 2005. Communicative constructions in English and Spanish. In Christopher S. Butler, María de los Ángeles Gómez González \& Susana Doval-Suárez (eds.), The dynamics of language use, 79-109. Amsterdam \& Philadelphia, PA: John Benjamins.

Paradis, Carita. 2004. Where does metonymy stop? Senses, facets and active zones. Metaphor and Symbol 19.4, 245-264.

Paradis, Carita. 2005. Ontologies and construals in lexical semantics. Axiomathes 15, 541-573.

Paradis, Carita. 2015a. Meanings of words: Theory and application. In Ulrike Hass \& Petra Storjohann (eds.), Handbuch Wort und Wortschatz (Handbücher Sprachwissen-HSW Band 3), 274-294. Berlin: Mouton de Gruyter.

Paradis, Carita. 2015b. Conceptual spaces at work in sensuous cognition: Domains, dimensions and distances. In Frank Zenker \& Peter Gärdenfors (eds.), Applications of conceptual spaces: Geometric knowledge representation, 33-55. Dordrecht: Springer.

Paradis, Carita. 2016. Corpus methods for the investigation of antonyms across languages. In Päivi Juvonen \& Maria Koptjevskaja-Tamm (eds.), The lexical typology of semantic shifts, 131-156. Berlin: Mouton de Gruyter.

Rodríguez Ramalle, Teresa María. 2008. Estudio sintáctico y discursivo de algunas estructuras enunciativas y citativas del español. Revista Española de Lingüística Aplicada 21, 269-288.

Rojo, Ana \& Javier Valenzuela. 2001. How to say things with words: Ways of saying in English and Spanish. META 46.3, 467-477.

Rudzka-Ostyn, Brygida. 1988. Semantic extensions into the domain of verbal communication. In Brygida Rudzka-Ostyn (ed.), Topics in cognitive linguistics, 507-553. Amsterdam \& Philadelphia, PA: John Benjamins.

Slobin, Dan I. 1996. Two ways to travel: Verbs of motion in English and Spanish. In Masayoshi Shibatani \& Sandra A. Thompson (eds.), Grammatical constructions: Their form and meaning, 195-220. Oxford: Clarendon Press.

Slobin, Dan I. 2004. The many ways to search for a frog: Linguistic typology and the expression of motion events. In Sven Strömqvist \& Ludo Verhoeven (eds.), Relating events in narrative: Typological and contextual perspectives, 219-257. Mahwah, NJ: Lawrence Erlbaum.

Slobin, Dan I. 2006. What makes manner of motion salient? Explorations in linguistic typology, discourse, and cognition. In Maya Hickmann \& Stéphane Robert (eds.), Space in languages: Linguistic systems and cognitive categories, 59-81. Amsterdam \& Philadelphia, PA: John Benjamins.

Slobin, Dan I., Iraide Ibarretxe-Antunano, Anetta Kopecka \& Asifa Majid. 2014. Manners of human gait: A crosslinguistic event-naming study. Cognitive Linguistics 25.4, 701-741.

Suñer, Margarita. 2000. The syntax of direct quotes with special reference to Spanish and English. Natural Language \& Linguistic Theory 18, 527-578.

Tannen, Deborah. 1986. Introducing constructed dialogue in Greek and American conversational and literary narrative. In Coulmas (ed.), 311-332.

Tannen, Deborah. 1995. Waiting for the mouse: Constructed dialogue in conversation. In Dennis Tedlock \& Bruce Mannheim (eds.), The dialogic emergence of culture, 198-217. Urbana, IL \& Chicago, IL: University of Illinois Press. 
Tannen, Deborah. 2007. Talking voices: Repetition, dialogue, and imagery in conversational discourse. Cambridge: Cambridge University Press.

Thompson, Geoff. 1996. Voices in the text: Discourse perspectives on language reports. Applied Linguistics 17, 501-530.

Talmy, Leonard. 1985. Lexicalization patterns: Semantic structure in lexical forms. In Timothy Shopen (ed.), Language typology and lexical descriptions, vol. 3: Grammatical categories and the lexicon, 36-149. Cambridge: Cambridge University Press.

Talmy, Leonard. 1988. Force dynamics in language and cognition. Cognitive Science 12, 49-100.

Talmy, Leonard. 1991. Paths to realization: A typology of event conflation. In Kathleen Hubbard (ed.), Proceedings of the Seventeenth Meeting of the Berkeley Linguistics Society (BLS 17), 480-519. Berkeley, CA: Berkeley Linguistics Society.

Talmy, Leonard. 2000. Toward a cognitive semantics. Cambridge, MA: MIT Press.

Vandelanotte, Lieven. 2012. Quotative go and be like: Grammar and grammaticalization. In Buchstaller \& van Alphen (eds.), 173-202.

Verschueren, Jeff (ed.). 1987. Linguistic action: Some empirical-conceptual studies. Norwood, NJ: Ablex.

Wierzbicka, Anna. 1987. English speech act verbs: A semantic dictionary. Sydney: Academic Press.

Zlatev, Jordan, Johan Blomberg \& Caroline David. 2010. Translocation, language and the categorization of motion. In Vyvyan Evans \& Paul Chilton (eds.), Language, cognition and space: The state of the art and new directions, 389-418. London: Equinox.

\section{Authors'addresses: (Caballero)}

Facultad de Letras, Universidad de Castilla-La Mancha,

Avda. Camilo José Cela, s/n 13071 Ciudad Real, Spain

MRosario.Caballero@uclm.es

(Paradis)

Centre for Languages and Literature, Lund University, BOX 201, 22100 Lund, Sweden

carita.paradis@englund.lu.se 